\title{
Review \\ Production of Light Olefins via Fischer-Tropsch Process Using Iron-Based Catalysts: A Review
}

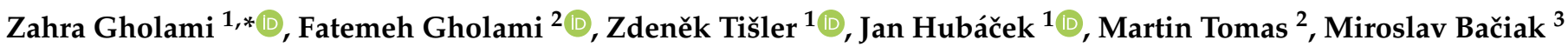 \\ and Mohammadtaghi Vakili ${ }^{4}$
}

1 ORLEN UniCRE, a.s., Revoluční 1521/84, 40001 Ústí nad Labem, Czech Republic; Zdenek.Tisler@orlenunicre.cz (Z.T.); Jan.Hubacek@orlenunicre.cz (J.H.)

2 New Technologies-Research Centre, University of West Bohemia, Veleslavínova 42, 30100 Plzeň, Czech Republic; gholami@ntc.zcu.cz (F.G.); mtomas@ntc.zcu.cz (M.T.)

3 ENRESS s.r.o., V zářezu 902/4, Jinonice, 15800 Prague, Czech Republic; baciak.m@tiscali.cz

4 Green Intelligence Environmental School, Yangtze Normal University, Chongqing 408100, China; mvakili1981@yahoo.com

* Correspondence: Zahra.Gholami@orlenunicre.cz; Tel.: +420-471-122-239

\section{check for}

updates

Citation: Gholami, Z.; Gholami, F.; Tišler, Z.; Hubáček, J.; Tomas, M.; Bačiak, M.; Vakili, M. Production of Light Olefins via Fischer-Tropsch Process Using Iron-Based Catalysts: A Review. Catalysts 2022, 12, 174. https://doi.org/10.3390/ catal12020174

Academic Editor: Valeria La Parola

Received: 12 January 2022

Accepted: 27 January 2022

Published: 28 January 2022

Publisher's Note: MDPI stays neutral with regard to jurisdictional claims in published maps and institutional affiliations.

Copyright: (C) 2022 by the authors. Licensee MDPI, Basel, Switzerland. This article is an open access article distributed under the terms and conditions of the Creative Commons Attribution (CC BY) license (https:// creativecommons.org/licenses/by/ $4.0 /)$.

\begin{abstract}
The production of light olefins, as the critical components in chemical industries, is possible via different technologies. The Fischer-Tropsch to olefin (FTO) process aims to convert syngas to light olefins with high selectivity over a proper catalyst, reduce methane formation, and avoid the production of excess $\mathrm{CO}_{2}$. This review describes the production of light olefins through the FTO process using both unsupported and supported iron-based catalysts. The catalytic properties and performances of both the promoted and bimetallic unsupported catalysts are reviewed. The effect of support and its physico-chemical properties on the catalyst activity are also described. The proper catalyst should have high stability to provide long-term performance without reducing the activity and selectivity towards the desired product. The good dispersion of active metals on the surface, proper porosity, optimized metal-support interaction, a high degree of reducibility, and providing a sufficient active phase for the reaction are important parameters affecting the reaction. The selection of the suitable catalyst with enhanced activity and the optimum process conditions can increase the possibility of the FTO reaction for light-olefins production. The production of light olefins via the FTO process over iron-based catalysts is a promising method, as iron is cheap, shows higher resistance to sulfur, and has a higher WGS activity which can be helpful for the feed gas with a low $\mathrm{H}_{2} / \mathrm{CO}$ ratio, and also has higher selectivity towards light olefins.
\end{abstract}

Keywords: olefin production; Fischer-Tropsch; iron catalyst; promoter; support

\section{Introduction}

As the key components in chemical industries, light olefins (ethylene, propylene, butenes, and butadiene) are used to produce many different derivatives used in our daily lives [1]. As a result of the strong demand for the production of polyethylene, its production is expected to increase from 169 million metric tons (MMT) to 210 MMT in 2022, whereas ethylene can be used for the production of polyethylene, polyvinylchloride, etc. With the production of about $116 \mathrm{MMT}$ in 2017, propylene is used to produce polypropylene, acrylonitrile, etc., and its demand is expected to reach 142 MMT in 2021 [2]. The annual production of butenes is around $132 \mathrm{MMT}$, and among them, isobutene is mainly used as raw material for the production of alkylates and also to produce high octane additives for gasoline blending, including MTBE and ETBE. Purified $C_{5}-C_{8}$ linear $\alpha$-olefins can be used as comonomers in the production of polyethylene, and the longer chain olefins can be transformed into linear alcohols via hydroformylation $[1,3]$. Syngas-based processes are known as a possible solution for light olefins production. The different processes for the production of light olefins from syngas produced from coal, natural gas, or biomass-based 
feedstocks are shown in Figure 1 [4]. The step for adjusting the $\mathrm{H}_{2} / \mathrm{CO}$ ratio using the water gas shift (WGS) reaction $\left(\mathrm{CO}+\mathrm{H}_{2} \mathrm{O} \rightleftharpoons \mathrm{CO}_{2}+\mathrm{H}_{2}\right)$ is unnecessary for the $\mathrm{H}_{2}$-rich syngas. The production of light olefins from syngas is divided into two main groups of indirect and direct processes.

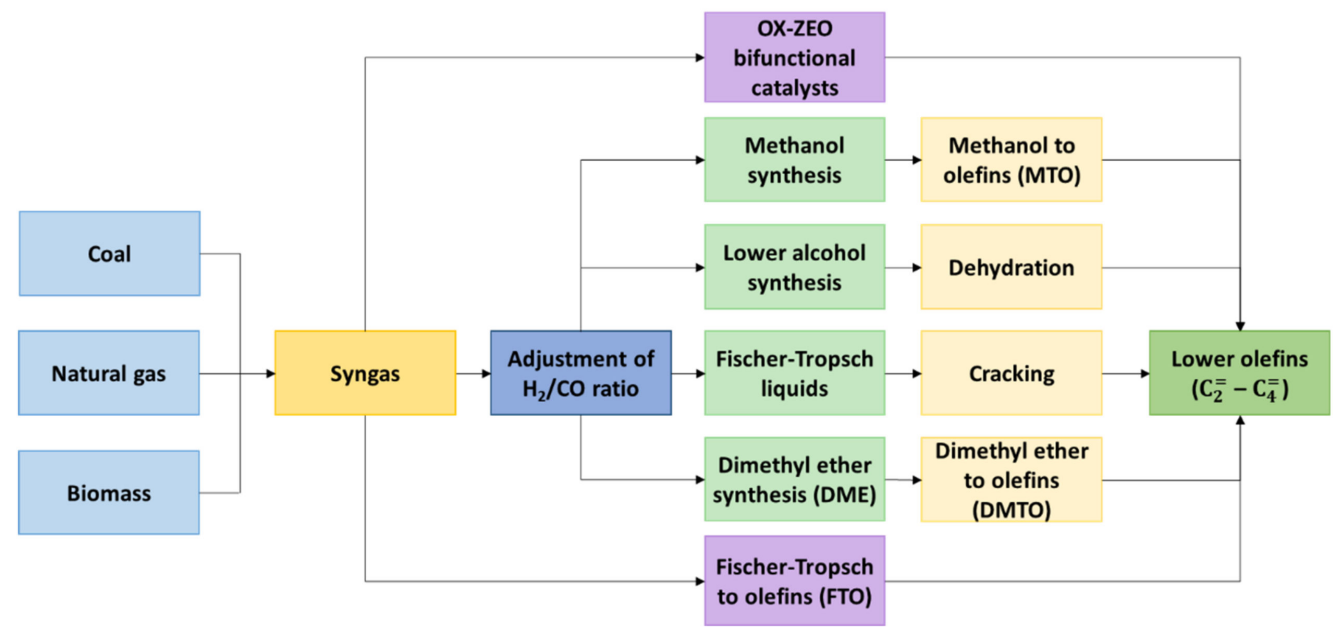

Figure 1. Processes for the transformation of CO-rich synthesis gas into light olefins [4].

During indirect processes, syngas is first converted into an intermediate product such as alcohol, Fischer-Tropsch liquids, or dimethyl ether (DME), and then the intermediate is converted to light olefins via other processes such as methanol to olefins (MTO), dehydration, cracking, or dimethyl ether to olefins (DMTO). In the direct process, syngas is directly converted into light olefins via Fischer-Tropsch synthesis (Fischer-Tropsch to olefins: FTO) or OX-ZEO process [4-7]. In 2016, Jiao et al. [8] reported that the OX-ZEO catalyst system could be used for the direct conversion of syngas to olefins; using the $\mathrm{ZnCrO} / \mathrm{MSAPO}$ catalyst at the reaction temperature of $400{ }^{\circ} \mathrm{C}$ and $25 \mathrm{bar}$, the selectivity of $94 \%$ to $\mathrm{C}_{2}-\mathrm{C}_{4}$ hydrocarbons and an $80 \%$ selectivity to $C_{2}-C_{4}$ olefins at the $C O$ conversion of $17 \%$ were obtained. FTO is another direct route for olefin production from syngas, and this method with moderate reaction conditions has attracted more attention from both the industry and academia.

\section{FTO Reaction}

Fisher-Tropsch synthesis (FTS), a strongly exothermic reaction, is generally used for the catalytic conversion of syngas to higher hydrocarbons and oxygenates, which could be upgraded to sulfur- and aromatic-free chemicals and transportation fuels [9,10]. Through catalytic-polymerization reactions, syngas is converted into a wide range of products such as paraffins, olefins, alcohols, and aldehydes. Paraffins and olefins are the primary products are FTS (Equations (1) and (2)).

$$
\begin{gathered}
(2 \mathrm{n}+1) \mathrm{H}_{2}+\mathrm{nCO} \rightarrow \mathrm{C}_{\mathrm{n}} \mathrm{H}_{2 \mathrm{n}+2}+\mathrm{nH}_{2} \mathrm{O} \\
2 \mathrm{n}_{2}+\mathrm{nCO} \rightarrow \mathrm{C}_{\mathrm{n}} \mathrm{H}_{2 \mathrm{n}}+\mathrm{nH}_{2} \mathrm{O}
\end{gathered}
$$

Briefly, $\mathrm{CO}$ undergoes dissociative or hydrogen-assisted dissociative chemisorption on the surface of active metal phases to produce the intermediate monomers of $\mathrm{CH}_{\mathrm{x}}$ $(x=0-3)$ for polymerization. The coupling of $\mathrm{CH}_{x}$ monomers results in the formation of $\mathrm{C}_{\mathrm{n}} \mathrm{H}_{\mathrm{m}}$ intermediates and chain growth. The formed $\mathrm{C}_{\mathrm{n}} \mathrm{H}_{\mathrm{m}}$ intermediates with different carbon numbers can undergo hydrogenation or dehydrogenation to produce paraffins or olefins as the final products [11]. In general, due to the polymerization mechanism, the distribution of the product in the FTS process follows the Anderson-Schulz-Flory (ASF) distribution [12]. According to the ASF distribution, the weight fraction $\left(W_{n}\right)$ of the 
hydrocarbon product with the carbon number of $\mathrm{n}$ depends on the chain growth probability $(\alpha)$ (Equation (3)), and $\alpha$ is a function of the propagation rate $\left(r_{p}\right)$ and termination rate $\left(r_{t}\right)$ (Equation (4)) $[10,13,14]$.

$$
\begin{gathered}
\frac{W_{n}}{n}=(1-\alpha)^{2} \times \alpha^{(n-1)} \\
\alpha=\frac{r_{p}}{r_{p}+r_{t}}
\end{gathered}
$$

The FTO process aims to maximize the production of light olefins, decrease the selectivity to methane, and avoid the production of extra $\mathrm{CO}_{2}$. As can be seen in the ASF distribution plot, the highest selectivity to $C_{2}-C_{4}$ components is achieved at an $\alpha$ value in the range of 0.4 to 0.5 , and due to the limitation of the ASF distribution, it is generally difficult to achieve high selectivity to $\mathrm{C}_{2}-\mathrm{C}_{4}$ olefins. Increasing the reaction temperature could help to shift the selectivity to $\mathrm{C}_{2}-\mathrm{C}_{4}$ by lowering the $\alpha$ value; however, at the same time, it could increase the selectivity to methane; and it is the main restriction for the industrial application of the FTO process. These drawbacks are attributed to the FTS reaction mechanism via the surface polymerization of $\mathrm{CH}_{\mathrm{x}}$ by adsorption of $\mathrm{CH}_{\mathrm{x}}$ monomers to the adsorbed alkyl species on the open metal surfaces. Therefore, a wide range of hydrocarbons with different chain lengths are produced, and according to the ASF model, the highest selectivity to $\mathrm{C}_{2}-\mathrm{C}_{4}$ hydrocarbons, including olefins and paraffins, is about $57 \%$ [8]. The high-temperature reaction using Fe-based catalysts in the fluidized-bed reactors is ideal for the production of linear $\alpha$-olefins. The addition of promoters can also alter the catalyst properties and increase the catalyst activity or enhance the selectivity to light olefins. Dispersion of the active metals on a support material can increase the surface area of the active metals, and the addition of a structural promoter can improve the mechanical stability of the catalyst.

The FT reaction is a surface polymerization reaction, and the product stream contains a range of products instead of a single component. The reaction follows these steps: (1) reactant adsorption, (2) chain initiation, (3) chain growth, (4) chain termination, (5) product desorption, (6) readsorption and further reaction. Different surface species, including reactants (species 1, 2, 3, 4, 5), oxygen-containing intermediates (species 6, 7, 8), and hydrocarbon intermediates (species 9, 10,11,12), were suggested for the description of the chain initiation and chain growth (Figure 2A) [15]. The most active layer is immediately next to (and bonded to) the metal surface and contains $\mathrm{C}, \mathrm{O}$, and $\mathrm{H}$ atoms and at least two types of adsorbed CO. Next to the first layer is a layer of physisorbed $\mathrm{CO}, \mathrm{H}_{2}$, and desorbed products [16].

Two reaction mechanisms of carbide and $\mathrm{CO}$ insertion chain growth are suggested for the FT reaction, while the carbide mechanism is known as the most important mechanism for the formation of hydrocarbons on iron, cobalt, and ruthenium catalysts [15]. In this mechanism, the $\left(-\mathrm{CH}_{2}-\right)$ species (species 10) is the initiating monomer (Figure 2B). It is assumed that the $\mathrm{CO}$ and $\mathrm{H}_{2}$ are adsorbed dissociatively and incorporated into the chain growth, and several $\mathrm{CH}_{\mathrm{x}}$ species, such as $\mathrm{CH}$ (species 9), $\mathrm{CH}_{2}$ (species 10), and $\mathrm{CH}_{3}$ (species 11), can be formed. The chain growth occurs via the insertion of the monomer in a growing alkyl species (species 12), and - $\mathrm{CH}_{2}$ - monomers can be polymerized to long-chain hydrocarbons. The last step is the termination of the products, which occurs by the addition of a $-\mathrm{CH}_{3}$ species or hydrogen to produce an alkane or by the loos of hydrogen to form an alkene [15]. 


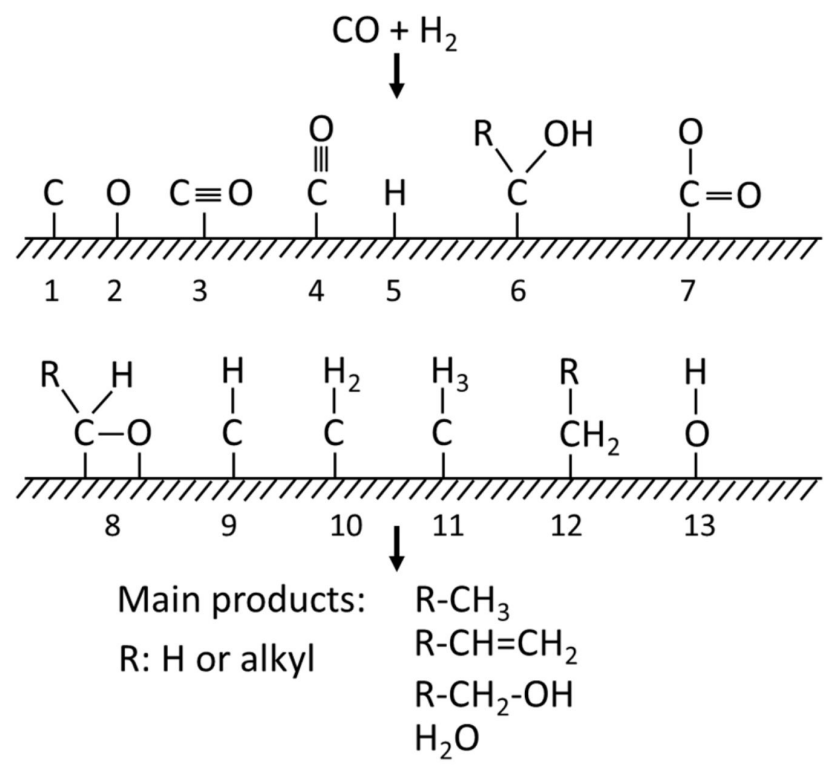

(A)

(1)
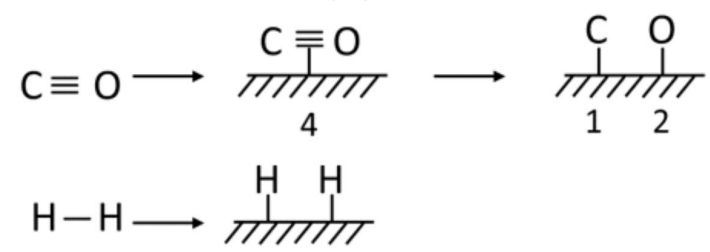

5

(2)

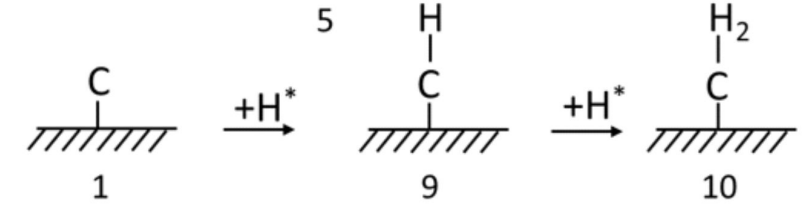

(3)<smiles>CCC</smiles>

10

$\mathrm{R}$<smiles>[R]CC([18F])[18F]</smiles>

12

$\mathrm{R}-\mathrm{CH}=\mathrm{CH}_{2}$<smiles>[R]CCC=[V]</smiles>

12

(4)

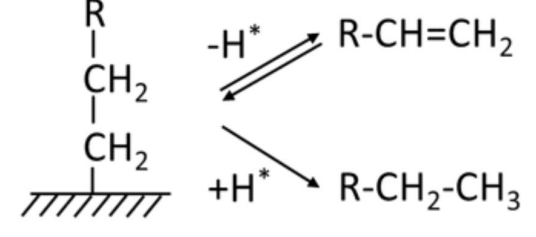

12

(B)

Figure 2. (A) Observed and proposed chemisorbed species during Fischer-Tropsch. Synthesis; (B) Reaction scheme of the Fischer-Tropsch reaction according to carbide mechanism [15].

\section{FTO Catalysts}

The production of light olefins with high selectivity is the main challenge in the industrial application of the FTO process, and extensive efforts have been made to develop an efficient catalyst that can break the ASF distribution and promote high selectivity to light olefins. Iron and cobalt-based catalysts are mainly used for the FTO process. Cobalt-based 
catalysts have higher catalytic activity and stability, and lower activity to water gas shift (WGS). However, the selectivity to light olefins over the cobalt-based catalysts was lower than that required for industrial applications. Both iron and cobalt-based catalysts have been widely used in commercial plants of FT synthesis [9,17-23]. The Sasol FT plant in Sasolburg (Sasol 1) was developed for the production of petrol in the circulating fluidizedbed (CFB) reactors over Fe/K catalyst using high-temperature Fisher-Tropsch (HTFT) technology (at 320-350 ${ }^{\circ} \mathrm{C}$ ) and low-temperature Fisher-Tropsch (LTFT) technology (at $200-250^{\circ} \mathrm{C}$ ) for the production of waxes in the multitubular fixed-bed reactor (in 1955) and slurry reactor (in 1993). Sasol 2 and 3 plants were constructed in Secunda, South Africa, in 1980 and 1983 using fused Fe/K catalyst in CFB reactors and HTFT process, and later in 1995, the Sasol Advanced Synthol (SAS) reactors for the HTFT process were used by Sasol in Secunda.

The first FT plants using natural gas as feedstock were developed by Shell in Bintulu, Malaysia (1993), using the cobalt-based catalysts $\left(\mathrm{Co} / \mathrm{SiO}_{2}, \mathrm{Co} / \mathrm{TiO}_{2}\right)$ in a multitubular fixed-bed reactor and LTFT technology $[20,21]$. The HTFT technology using a CFB reactor and fused $\mathrm{Fe} / \mathrm{K}$ catalysts were also used in another FT plant by Petro SA in Mosselbay, South Africa. The Sasol-QP (Oryx) plant in Ras Laffan, Qatar, uses the LTFT technology and $\mathrm{Co}-\mathrm{Al}_{2} \mathrm{O}_{3}$ catalysts in the slurry phase reactors. Other plants using LTFT, mediumtemperature slurry-bed FT process (MTFT), and HTFT technologies using iron- and cobaltbased catalysts were later developed in China and Nigeria. The HTFT technology has been traditionally applied for gasoline production, but it has subsequently been reconfigured for maximum olefin production using the optimized catalyst [24].

Depending on the desired products, LTFT technology or HTFT technology is used with iron or cobalt catalysts. In order to minimize methane formation, the FTS temperatures are usually kept below $400{ }^{\circ} \mathrm{C}$. High molecular-weight linear waxes are produced in LTFT processes, while low molecular weight olefins are produced in HTFT processes [25,26]. FT reactors are operated at pressures in the range of 10-40 bar. The effect of different parameters on product selectivity is shown in Table 1 [15,27]. The formation of lower molecular weight hydrocarbons increases by increasing the reaction temperature over iron, cobalt, and ruthenium catalysts. The effect of temperature on the olefin selectivity is complex since some researchers reported an increase in the selectivity by increasing the temperature, while others reported the opposite behavior [15]. Promotion of catalysts with alkali metals and increasing the space velocity during the reaction positively affect the olefin selectivity. At a higher $\mathrm{H}_{2} / \mathrm{CO}$ ratio, the product selectivity shifts to the lighter products, and olefin selectivity decreases.

Table 1. Selectivity control in Fischer-Tropsch synthesis by reaction parameters and catalyst modifications. Reprinted with permission from Ref. [15]. Copyright (2022) Informa UK Limited.

\begin{tabular}{|c|c|c|c|c|c|c|}
\hline Parameter & $\begin{array}{l}\text { Chain } \\
\text { Length }\end{array}$ & $\begin{array}{c}\text { Chain } \\
\text { Branching }\end{array}$ & $\begin{array}{c}\text { Olefin } \\
\text { Selectivity }\end{array}$ & $\begin{array}{c}\text { Alcohol } \\
\text { Selectivity }\end{array}$ & $\begin{array}{c}\text { Carbon } \\
\text { Deposition }\end{array}$ & $\begin{array}{l}\text { Methane } \\
\text { Selectivity }\end{array}$ \\
\hline Temperature & $\mathrm{D}$ & I & $\mathrm{C}$ & $\mathrm{D}$ & I & I \\
\hline Pressure & I & $\mathrm{D}$ & $\mathrm{C}$ & I & $\mathrm{C}$ & $\mathrm{D}$ \\
\hline $\mathrm{H}_{2} / \mathrm{CO}$ & $\mathrm{D}$ & $\mathrm{I}$ & $\mathrm{D}$ & $\mathrm{D}$ & $\mathrm{D}$ & $\mathrm{I}$ \\
\hline Conversion & $\mathrm{C}$ & $\mathrm{C}$ & $\mathrm{D}$ & $\mathrm{D}$ & I & I \\
\hline Space velocity & $\mathrm{C}$ & $\mathrm{C}$ & I & I & $\mathrm{C}$ & $\mathrm{D}$ \\
\hline Alkali content of iron catalyst & $\mathrm{I}$ & $\mathrm{D}$ & $\mathrm{I}$ & $\mathrm{I}$ & I & $\mathrm{D}$ \\
\hline
\end{tabular}

(I): Increase with increasing parameter, (D): Decrease with increasing parameter: (C): Complex relation.

The formation of long-chain hydrocarbons and olefin selectivity increase by increasing space velocity. The reduced $\mathrm{CO}$ conversion results in higher olefin selectivity, and a large fraction of unreacted syngas undergoes separation. However, recycling the unreacted syngas improves the $\mathrm{CO}$ conversion rate, but it requires a larger separation unit and FTO reactor, which can increase the total capital costs. Iron-based catalysts have lower methanation activity and reveal more resistance against contaminants $[5,28,29]$. These 
catalysts are more selective to olefins than Co- or Ru-based FT catalysts. The higher WGS activity over the iron catalyst is another advantage of this catalyst and made them an attractive option for using $\mathrm{CO}$-rich syngas derived from coal or biomass, because the additional step for the $\mathrm{H}_{2} / \mathrm{CO}$ adjustment is unnecessary. When olefins are the desired products of the FT reaction, promoted iron catalysts provide the best option.

\section{Iron-Based Catalysts}

\subsection{Unsupported Iron-Based Catalysts}

Iron-based catalysts are usually prepared in the 'bulk' form. The catalyst is prepared by fusing magnetite with a small amount of promoter for the HTFT process, and for the LTFT process, the catalyst is prepared by precipitation method. Iron-based catalysts were widely used and studied to directly produce light olefins via FT reaction [5,19,29-35]. Although promoted (unsupported) iron oxide catalysts exhibited high selectivity to light olefins (up to $70 \%$ ), bulk iron catalysts are mechanically unstable at high reaction temperatures. The poor mechanical stability of the bulk iron catalysts may result in the plugging of the catalyst bed in fixed-bed reactors or fouling of separation equipment in a fluidized-bed process [30]. For cobalt catalysts, the metallic state is the active phase, while for the iron catalysts, iron carbides, iron oxides, and even metallic iron were reported to act as active sites [28,35-37]. As shown in Figure 3, the fresh iron catalysts, which are comprised of both ferromagnetic (fm) and superparamagnetic (sp) structures of $\alpha-\mathrm{Fe}_{2} \mathrm{O}_{3}$ (hematite), are first reduced to $\mathrm{Fe}_{3} \mathrm{O}_{4}$ in both bulk and surface regions [37].

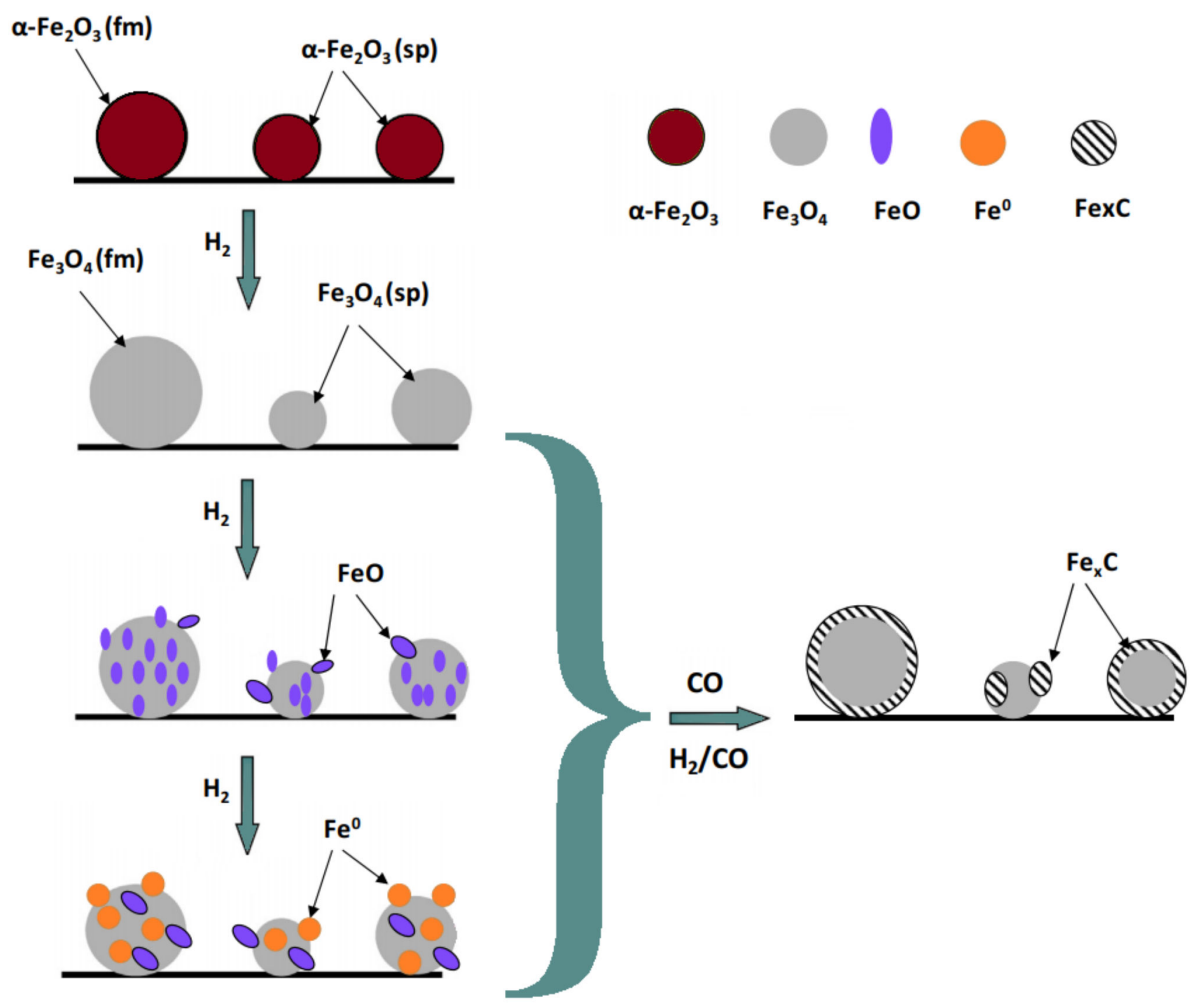

Figure 3. Reduction and carburization behaviors of an iron-based catalyst [37].

The $\mathrm{Fe}_{3} \mathrm{O}_{4}$ is then reduced to the metastable $\mathrm{FeO}$, which is finally reduced to metallic Fe $(\alpha-\mathrm{Fe})$. Later, when the reduced catalyst is exposed to $\mathrm{CO}$ or syngas atmosphere, these reduced species are converted to iron carbides (especially $\chi-F_{5} C_{2}$ ), which positively provide the FTS active sites. The carburization ability of different reduced species is in the order $\alpha$-Fe $>\mathrm{FeO}>\mathrm{Fe}_{3} \mathrm{O}_{4}$ [37]. During the FT reaction, different forms of iron oxides and iron carbides $\left(\mathrm{Fe}_{\mathrm{x}} \mathrm{C}_{\mathrm{y}}\right)$ may co-exist, i.e., $\alpha$-Fe, $\gamma-\mathrm{Fe}, \mathrm{Fe}_{3} \mathrm{O}_{4}, \mathrm{FeO}$, co-existing with $\varepsilon-\mathrm{Fe}_{2} \mathrm{C}$, 
$\varepsilon^{\prime}-\mathrm{Fe}_{2.2} \mathrm{C}, \chi-\mathrm{Fe}_{5} \mathrm{C}_{2}$ (Hägg carbide), $\mathrm{Fe}_{7} \mathrm{C}_{3}$, and $\theta-\mathrm{Fe}_{3} \mathrm{C}[31,38,39]$. The structural models of $\varepsilon$-carbide, Hägg carbide, and magnetite $\left(\mathrm{Fe}_{3} \mathrm{O}_{4}\right)$ are shown in Figure $\mathrm{S} 1$ [38].

Boudart and McDonald [40] reported that iron particles are converted to bulk carbides during FT reactions and hydrocarbon synthesis. The nature of iron carbides is affected by the particle size of the catalysts. The Mössbauer effect spectroscopy studies revealed that the hexagonal close-packed $\varepsilon$-carbide $\mathrm{Fe}_{2} \mathrm{C}$ developed in small particles, while $\chi$-carbide $\mathrm{Fe}_{5} \mathrm{C}_{2}$ developed in larger particles. Several characterizations and theoretical analyses revealed that Hägg iron carbide $\left(\chi-\mathrm{Fe}_{5} \mathrm{C}_{2}\right)$ is the dominant active phase of iron-based FT catalysts $[41,42]$. The $\mathrm{Fe}_{2} \mathrm{O}_{3}$ nanoparticles grown on iron foil via a controlled process involving hydrothermal growth and calcinations were studied by Sun et al. [43]. The catalyst showed a high CO conversion rate of $86.7 \%$ with long-term stability of $200 \mathrm{~h}$, and the selectivity of $C_{2}-C_{4}$ olefins and $C_{2}-C_{4}$ paraffins were $44.7 \%$ and $18.6 \%$ after $200 \mathrm{~h}$ of reaction at $300{ }^{\circ} \mathrm{C}, 2.0 \mathrm{MPa}$, and $\mathrm{H}_{2} / \mathrm{CO}=2$. Prior to the $\mathrm{FTO}$ reaction, the catalyst was activated at $400{ }^{\circ} \mathrm{C}$ and $2.0 \mathrm{MPa}$, under $\mathrm{H}_{2}$ for $4 \mathrm{~h}$. After the FTO reaction, $\mathrm{Fe}_{2} \mathrm{O}_{3}$ is changed to $\mathrm{Fe}_{3} \mathrm{O}_{4} @ \mathrm{Fe}_{5} \mathrm{C}_{2}$ nanoparticles, maintaining a carburized surface with suitable carbides particle size and thus increasing the $\mathrm{CO}$ conversion.

\subsubsection{Promoted Fe-Based Catalysts}

Since the discovery of the FT process, the addition of potassium as a promoter to the iron-based catalysts has been implemented to increase the basicity of the catalyst surface, aiming to increase the $\mathrm{CO}$ adsorption on the metal surface and withdrawing electrons from the metal by providing an electron donor. Alkali promoters could increase the $\mathrm{CO}$ dissociative adsorption rate, increase the surface coverage of dissociated $\mathrm{CO}$, inhibit the olefin readsorption, and thus increase the olefin selectivity [38]. The basicity of the catalyst and adsorption of $\mathrm{CO}$ and $\mathrm{CO}_{2}$ increase by the addition of $\mathrm{K}_{2} \mathrm{O}$ to the iron catalysts, resulting in an increased chain growth and catalytic activity and enhancing the WGS reaction. Hydrogenation of adsorbed carbon species decreases by the addition of $\mathrm{K}_{2} \mathrm{O}$ to the Fe catalysts, improves chain growth, and enhances the formation of more olefinic products with higher molecular weight. Potassium-promoted Fe catalysts also have higher WGS activity, resulting in a faster rate of catalyst deactivation due to the carbon deposition on the catalyst surface [25]. The rate of the FT reaction can also be increased by employing copper as a promoter for Fe catalysts, which can facilitate the reduction of iron. The copper-promoted catalyst shows a lower rate of WGS reaction than potassium promoted catalyst. The average molecular weight of the products in the potassium-promoted catalysts is higher than those of copper-promoted catalysts. Due to their high affinity to carbon monoxide, transition metals such as titanium, manganese, and vanadium were reported to be excellent promoters for olefin production [44]. Different elements such as potassium, sodium, manganese, titanium, vanadium, and zinc have been investigated as promising promoters to enhance the selectivity to $\mathrm{C}_{2}-\mathrm{C}_{4}$ olefins [38,45-53].

The iron-based catalysts were used in the LTFT process by Sasol to produce waxes in both fixed- and slurry-bed reactors. The catalyst was originally developed by Ruhrchemie, who dissolved scrap iron of a suitable chemical composition, together with metallic copper ( $40 \mathrm{~g}$ Fe and $2 \mathrm{~g} \mathrm{Cu}$ per liter),in nitric acid, supported on $\mathrm{SiO}_{2}\left(25 \mathrm{~g} \mathrm{SiO}_{2}\right.$ per $100 \mathrm{~g} \mathrm{Fe}$ ); a typical catalyst contains $25 \mathrm{~g} \mathrm{SiO}_{2}, 5 \mathrm{~g} \mathrm{Cu}$, and $5 \mathrm{~g} \mathrm{~K}_{2} \mathrm{O}$ per $100 \mathrm{~g}$ Fe [24]. Rentech used an unsupported iron catalyst promoted by $1 \mathrm{~g}$ of $\mathrm{K}$ and $\mathrm{Cu}$ per $100 \mathrm{~g}$ of Fe. By increasing the ratio of $\mathrm{Fe} / \mathrm{Si}(\mathrm{Fe} / \mathrm{Si}>4)$, silica is unlikely to act as classical support, but acts as a binder and as a spacer, which can inhibit the sintering of iron with a high surface area. Sasol reported that the addition of potassium waterglass $\left(\mathrm{K}_{2} \mathrm{O}_{3} \mathrm{Si}\right)$ into the slurried hydrated ferric oxide precipitate resulted in the complete precipitation or adsorption of silica onto the high area iron precipitate. Subsequent washing was able to remove all of the potassium but none of the silica.

Luo and Davis [54] reported that the high $\mathrm{CO}_{2}$ formation over the potassium-promoted iron catalyst could be due to the higher WGS activity in this catalyst than the catalysts promoted by other metals of group II. The addition of alkali-earth elements $(\mathrm{Ca}, \mathrm{Mg})$ can sup- 
press the WGS activity below that of unpromoted iron catalysts. Compared with the unpromoted iron catalyst, alkali-earth promoted catalysts resulted in a higher yield of liquid products $\left(\mathrm{C}_{5+}\right)$ and lower gas fraction, while potassium-promoted catalyst produced lower liquid products and higher gas fractions. Alkali-earth promoted catalysts resulted in a slightly higher $\mathrm{C}_{2}-\mathrm{C}_{4}$ olefin ratio, while the potassium promoted catalyst resulted in a significantly higher ethylene yield than the catalysts promoted with group II metals [55]. The effect of alkali promoter (K and $\mathrm{Na})$ on the catalytic performance of $\mathrm{FeCu} / \mathrm{SiO}_{2}\left(100 \mathrm{Fe} / 6 \mathrm{Cu} / 19 \mathrm{SiO}_{2}\right)$ catalyst in FT reaction investigated by An et al. [48]. The promoted catalysts, $\mathrm{FeCuNa} / \mathrm{SiO}_{2}$ $\left(100 \mathrm{Fe} / 6 \mathrm{Cu} / 5 \mathrm{Na} / 19 \mathrm{SiO}_{2}\right)$, and $\mathrm{FeCuK} / \mathrm{SiO}_{2}\left(100 \mathrm{Fe} / 6 \mathrm{Cu} / 5 \mathrm{~K} / 19 \mathrm{SiO}_{2}\right)$ were prepared by a combination of precipitation and spray-drying methods. The surface basicity and carburization of the catalyst during the reduction and reaction improved for both K- and Na-promoted catalysts; this effect was weaker for the sodium-promoted catalyst. The results of the FT reaction (at $250{ }^{\circ} \mathrm{C}, 1.5 \mathrm{MPa}, \mathrm{H}_{2} / \mathrm{CO}=0.67,2000 \mathrm{~h}^{-1}, 300 \mathrm{~h}$ ) revealed that the catalyst activity increased over the promoted catalysts, and the formation of light olefins and heavier products increased, which was more evident for the potassium-promoted catalyst. The selectivity to methane also decreased after the incorporation of $\mathrm{Na}$ and $\mathrm{K}$.

The perovskite-like oxides with the composition of $\mathrm{La}_{1-x} \mathrm{~K}_{\mathrm{x}} \mathrm{Mn}_{\mathrm{y}} \mathrm{Fe}_{1-\mathrm{y}} \mathrm{O}_{3}(\mathrm{x} \geq 0$, $y \leq 0.2$ ) were prepared using the coprecipitation method and their catalytic performance for the production of light olefins via the FTO process investigated by Goldwasser et al. [55]. The results indicated that the activity of the catalyst was strongly related to the formation of Hägg carbides. The addition of potassium enhanced the reducibility to $\alpha$-Fe and resulted in the formation of a more carbide phase, and the production of light olefins also increased by the addition of $\mathrm{Mn}$. The selectivity to $\mathrm{C}_{2}-\mathrm{C}_{4}$ light olefins and catalyst stability was strongly modified in the presence of both $\mathrm{K}$ and $\mathrm{Mn}\left(\mathrm{La}_{0.9} \mathrm{~K}_{0.1} \mathrm{Fe}_{0.9} \mathrm{Mn}_{0.1} \mathrm{O}_{2.9}\right)$ when the catalyst was tested at $280{ }^{\circ} \mathrm{C}, 1.1 \mathrm{MPa}$, and $\mathrm{H}_{2} / \mathrm{CO}=2$ (Table S1). Different species, including $\alpha$-Fe, Hägg carbide, and mixed oxides of the perovskite-type, existed in $\mathrm{La}_{0.9} \mathrm{~K}_{0.1} \mathrm{FeO}_{2.9}$, $\mathrm{La}_{0.8} \mathrm{~K}_{0.2} \mathrm{FeO}_{2.8}$, and $\mathrm{LaMn}_{0.2} \mathrm{Fe}_{0.8} \mathrm{O}_{3}$ catalysts. The Hägg carbides play the main role in catalytic performances. For the $\mathrm{La}_{0.9} \mathrm{~K}_{0.1} \mathrm{Mn}_{0.1} \mathrm{Fe}_{0.9} \mathrm{O}_{2.9}$ catalyst, a $\mathrm{Fe}_{3} \mathrm{O}_{4}$ phase was also detected, which seems to be stabilized in the presence of Mn [55].

Özkara-Aydınoğlu et al. [51] sought to maximize the production of $\alpha$-olefin by controlling the secondary reactions of $\alpha$-olefin; therefore, they studied the effect of $\mathrm{K}$ and $\mathrm{Cu}$ promoters on the catalytic activity of precipitated Fe catalysts in FT reaction. The $\mathrm{Cu}-$ promoted catalysts exhibited a higher surface area, while the surface area decreased for the K-promoted catalysts. The formation of the $\mathrm{Fe}_{3} \mathrm{O}_{4}$ phase of iron was enhanced by increasing the potassium content. The selectivity to $\mathrm{CO}_{2}$ increased for the catalysts with a higher content of $\mathrm{K}$, but for the with a higher amount of $\mathrm{Cu}$, an increase in the $\mathrm{CO}_{2}$ selectivity was not as high, which could be due to the inhibition of WGS activity at higher $\mathrm{Cu}$ content. The selectivity to $\alpha$-olefins at different temperatures and space velocities is strongly related to the amount of $\mathrm{Cu}$ and $\mathrm{k}$ promoters and chain length. The maximum $\alpha$-olefin/n-paraffin ratio was obtained at $270{ }^{\circ} \mathrm{C}$ and space velocity of $3 \mathrm{NL} / \mathrm{h} / \mathrm{g}_{\text {cat }}$ over $100 \mathrm{Fe} 3 \mathrm{Cu} 1 \mathrm{~K}$ catalyst, which had the highest surface area among the other prepared catalysts in this study.

Tian et al. investigated the effect of the potassium promoter on the catalytic performance of iron carbide catalysts encapsulated in graphene-like carbon [56]. The catalysts were prepared via facile pyrolysis of iron-glucose precursor. Glucose acts as the precursor to form a carbon support, and it also acts as a reducing agent to reduce iron oxides to $\theta-\mathrm{Fe}_{3} \mathrm{C}$ during the catalyst preparation. Through a phase transformation, $\theta-\mathrm{Fe}_{3} \mathrm{C}$ can be transformed to $\chi-\mathrm{Fe}_{5} \mathrm{C}_{2}$ as the active phase in the FT reaction. The size of the iron carbide reduced from $42.7 \pm 19.9 \mathrm{~nm}$ to $29.9 \pm 13.9 \mathrm{~nm}$ via the addition of potassium (Figure $4 \mathrm{~A}-\mathrm{D}$ ). The amount of defects on the graphene-like layers also increased, and the formation of iron carbides during the catalyst preparation was facilitated. Results revealed that except the differences in the particle size of iron carbide, there are no differences in the morphology of promoted and unpromoted catalysts. The XRD analysis of catalysts (Figure 4E) showed that the addition of potassium did not considerably affect the crystal phase of the calcined catalysts. The weaker peak intensities of the K promoted catalysts compared to unpro- 
moted catalyst could be due to the smaller crystallite size of iron carbides in the promoted catalysts (according to the Scherrer equation), which is in good accordance with the TEM analysis. The first broad peak at $26.1^{\circ}$ is attributed to the graphitic carbon (002). The peaks belong to the $\mathrm{Fe}_{3} \mathrm{O}_{4}$ observed at $30.1^{\circ}$ and $35.4^{\circ}$, and the peaks of $\alpha$-Fe detected at $44.7^{\circ}$ and $65.0^{\circ}$. The intensities of the peaks $\left(\mathrm{Fe}_{3} \mathrm{O}_{4}\right.$ and $\alpha$-Fe) decreased by increasing the amount of $\mathrm{K}$ promoter, indicating the facilitated phase transformation of iron oxides to iron carbide during the catalyst preparation.
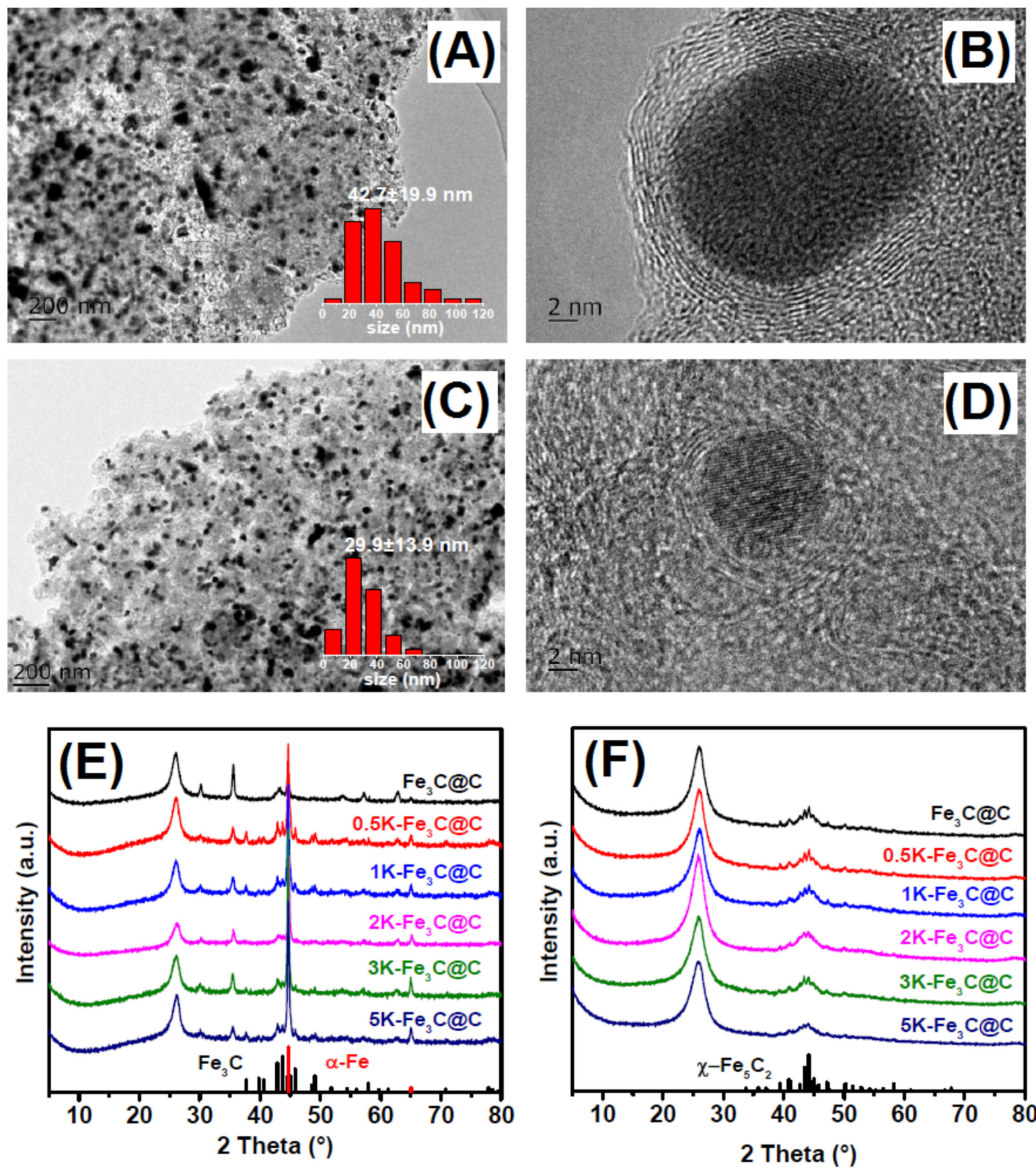

Figure 4. TEM and HRTEM images of $(\mathbf{A}, \mathbf{B})$ the as-prepared unpromoted $\mathrm{Fe}_{3} \mathrm{C} @ \mathrm{C}$ catalyst and $(\mathbf{C}, \mathbf{D})$ as-prepared $2 \mathrm{KFe}_{3} \mathrm{C} @ \mathrm{C}$ catalyst; XRD patterns of the $(\mathrm{E})$ calcined catalysts, and (F) reduced catalysts with different qualities of potassium promoter $(0-5 \mathrm{wt} \% \mathrm{~K})$. XRD patterns of the reduced catalysts were performed after reduction by $\mathrm{H}_{2} / \mathrm{CO}=1$ syngas flow for $12 \mathrm{~h}$ at $350^{\circ} \mathrm{C}$ and passivation by $1 \% \mathrm{O}_{2} / \mathrm{N}_{2}$ gas flow for $2 \mathrm{~h}$ in a quartz tube [56]. 
The peaks belong to iron oxides, metallic iron was not detected in the XRD patterns of the reduced catalysts, and the iron atoms existed in the Hägg carbide $\left(\chi-\mathrm{Fe}_{5} \mathrm{C}_{2}\right)$ form (Figure $4 \mathrm{~F}$ ), illustrating that the $\theta-\mathrm{Fe}_{3} \mathrm{C}$ phase in the calcined catalyst was transformed into $\chi-\mathrm{Fe}_{5} \mathrm{C}_{2}$ during the reduction. Due to the low potassium content and high dispersion in the catalyst, the peaks belonging to potassium were not detected in the XRD patterns of promoted catalysts. The potassium promoter probably existed in the form of $\mathrm{K}_{2} \mathrm{O}$, $\mathrm{KOH}$, or $\mathrm{K}_{2} \mathrm{CO}_{3}$ rather than metal potassium. The FTO reaction was carried out in a fixed-bed reactor at $320{ }^{\circ} \mathrm{C}, 20 \mathrm{bar}, \mathrm{H}_{2} / \mathrm{CO}=1$, and GHSV $=15,000 \mathrm{~mL} \cdot \mathrm{g}_{\text {cat }}{ }^{-1} \cdot \mathrm{h}^{-1}$. The highest selectivity of $\mathrm{C}_{2}-\mathrm{C}_{4}$ olefins (41.9\%) was obtained over the $2 \mathrm{~K}-\mathrm{Fe}_{3} \mathrm{C} @ \mathrm{C}$ catalyst. The electron-rich surfaces of these catalysts with the unique structure of graphene-like carbon layer encapsulated catalysts resulted in the difficult hydrogen adsorption and dissociation, and hydrogenation of the unsaturated intermediates could not occur easily. Consequently, the olefin selectivity increased.

A series of $\mathrm{Na}$ impregnated Fe-Zr catalysts $(\mathrm{Fe} / \mathrm{Zr}$ molar ratio $=100 / 15)$, prepared using the coprecipitation method, were used to evaluate the effect of $\mathrm{Zr}$ and $\mathrm{Na}$ on the physico-chemical properties of the catalysts and their catalytic performance in the hightemperature FT reaction [57]. The catalytic performances of the catalysts in FT reaction at $320^{\circ} \mathrm{C}, 1.5 \mathrm{MPa}$, and $\mathrm{H}_{2} / \mathrm{CO}=2$, are shown in Table 2 . In the presence of $\mathrm{Zr}$, which is a stable structure promoter, the growth of hematite crystallite size could be prohibited, and the specific surface area could be increased, resulting in the stabilization of active phases and improving the FT activity. The Na-promoted catalysts with larger pore sizes, enhanced the diffusion of reactants. As an electron promoter with a strong interaction with iron, $\mathrm{Na}$ showed the electron transfer from $\mathrm{Na}$ to Fe. The active sites for the dissociative adsorption of $\mathrm{H}_{2}$ and $\mathrm{CO}$ altered over the electron-rich iron catalysts, resulting in lower hydrogen adsorption and higher dissociative adsorption of $\mathrm{CO}$ on the surface of the catalyst. Consequently, the lower concentration of hydrogen at higher $\mathrm{Na}$ loading resulted in improved chain propagation and reduced the possibility of olefin hydrogenation. $\mathrm{Na}$ can facilitate iron carbonization, which might be responsible for the enhancement of $\mathrm{C}-\mathrm{C}$ coupling, and can preserve the iron carbide against oxidation, providing more active sites for the FT reaction.

Table 2. The catalytic activity of Fe-Zr catalysts. Reprinted with permission from Ref. [57]. Copyright (2022) American Chemical Society.

\begin{tabular}{|c|c|c|c|c|c|c|c|c|c|}
\hline \multirow{2}{*}{ Catalyst } & \multirow{2}{*}{$\begin{array}{c}\text { CO conv. } \\
(\%)\end{array}$} & \multirow{2}{*}{$\begin{array}{c}\mathrm{H}_{2} \text { conv. } \\
(\%)\end{array}$} & \multirow{2}{*}{$\begin{array}{c}\mathrm{CO}_{2} \text { sel. } \\
(\%)\end{array}$} & \multicolumn{4}{|c|}{ Hydrocarbon Selectivity (\%) } & \multirow{2}{*}{$\mathrm{O} / \mathrm{P}^{\mathrm{a}}$} & \multirow{2}{*}{$\begin{array}{c}\text { Mass Balance (\%) } \\
\mathrm{C}\end{array}$} \\
\hline & & & & $\mathrm{C}_{1}$ & $\mathrm{C}_{2}^{=}-\mathrm{C}_{4}^{=}$ & $\mathrm{C}_{2}^{0}-\mathrm{C}_{4}^{0}$ & $\mathrm{C}_{5+}$ & & \\
\hline $\mathrm{Fe}-\mathrm{Zr}-\mathrm{ONa}$ & 80.6 & 50.7 & 37.8 & 24.7 & 22.1 & 22.5 & 30.7 & 0.98 & 96.3 \\
\hline $\mathrm{Fe}-\mathrm{Zr}-0.25 \mathrm{Na}$ & 96.1 & 54.6 & 37.7 & 26.6 & 20.8 & 22.9 & 29.7 & 0.91 & 96.7 \\
\hline $\mathrm{Fe}-\mathrm{Zr}-0.5 \mathrm{Na}$ & 98.1 & 58.2 & 34.4 & 22.7 & 26.8 & 15.2 & 35.3 & 1.76 & 97.2 \\
\hline $\mathrm{Fe}-\mathrm{Zr}-1.0 \mathrm{Na}$ & 95.2 & 50.2 & 36.5 & 13.5 & 35.8 & 6.3 & 44.4 & 5.68 & 96.4 \\
\hline $\mathrm{Fe}-\mathrm{Zr}-1.5 \mathrm{Na}$ & 94.7 & 51.6 & 37.4 & 12.4 & 31.5 & 5.0 & 51.1 & 6.30 & 97.0 \\
\hline $\mathrm{Fe}-0.1 \mathrm{Na}$ & 40.9 & 30.1 & 34.9 & 15.7 & 32.3 & 6.2 & 45.8 & 5.21 & 95.5 \\
\hline
\end{tabular}

${ }^{a} \mathrm{O} / \mathrm{P}$ is in the range of $\mathrm{C}_{2}-\mathrm{C}_{4}$ hydrocarbons. Reaction conditions: $\mathrm{T}=320{ }^{\circ} \mathrm{C}, \mathrm{P}=1.5 \mathrm{MPa}, \mathrm{H}_{2} / \mathrm{CO}=2$, $10,000 \mathrm{~mL} / \mathrm{g} \cdot \mathrm{h}, 48 \mathrm{~h}$ of reaction.

\subsubsection{Fe-Based Bimetallic Catalysts}

Iron-based catalysts usually contain a small amount of $\mathrm{K}$ and other metals or metal oxides to increase their activity and selectivity. The selectivity to light olefins in the FT reaction can be increased by combining transition metal oxides with Fe catalysts. Manganese modified iron-based catalysts have been widely used to improve the selectivity to light olefins [58-64]. Incorporation of manganese oxide causes an increase in both activity and chain propagation; if $\mathrm{MnO}$ reacts with iron oxides, a spinel structure $\left(\left(\mathrm{Fe}_{1-\mathrm{x}} \mathrm{Mn}_{\mathrm{x}}\right)_{3} \mathrm{O}_{4}\right.$, $x<1$ ) could be obtained and increases the selectivity to light olefins [65,66]. Wang et al. [67] reported that the introduction of manganese to the Fe catalyst $(\mathrm{Mn}: F e$ atomic ratio $=4: 96)$ increased the CO conversion (from $91.8 \%$ to $96.3 \%$ ) and selectivity to $\mathrm{C}_{2}-\mathrm{C}_{4}$ olefins (from 
$26 \%$ to $52 \%$ ), while the CO conversion and selectivity to light olefins decreased following a further increase in the Mn content (Table S2). They also studied the effect of the catalyst preparation method (precipitation and sol-gel methods) on the activity and stability of the catalyst. The selectivity to light olefins for the samples prepared by the precipitation method was higher than those prepared by the sol-gel method. For the samples prepared by the sol-gel method, the selectivity to $C_{2}-C_{4}$ olefins increased by the addition of $\mathrm{Mn}$, and similar to the samples prepared by the precipitation method, the selectivity to light olefins decreased at higher Mn content.

A physico-chemical analysis of the prepared catalysts revealed that the catalysts with better reduction and carburization properties have a higher yield of light olefins, which could be due to the better regeneration of oxidized active sites in the syngas atmosphere after modification of Fe catalyst with Mn. Consequently, it can provide sufficient active sites on the catalyst's surface for the adsorption and decomposition of $\mathrm{CO}$. Thus, the improved carburization environment on the surface and the inhibited hydrogenation rate result in a high selectivity to light olefins [67]. The effect of reaction conditions on the catalytic performance of Fe-Mn bimetallic catalysts was studied by Liu et al. [68]. The selectivity to $\mathrm{C}_{2}-\mathrm{C}_{4}$ light olefins increased from $20.66 \mathrm{wt}$ \% to $22.98 \mathrm{wt}$ \% by increasing the space velocity from $1.07 \times 10^{-3} \mathrm{Nm}^{3} \cdot \mathrm{kg}_{\text {cat }}{ }^{-1} \cdot \mathrm{s}^{-1}$ to $2.90 \times 10^{-3} \mathrm{Nm}^{3} \cdot \mathrm{kg}_{\mathrm{cat}}{ }^{-} \cdot \mathrm{s}^{-1}$, while at the same time, the $\mathrm{CO}$ conversion decreased sharply from $81.8 \%$ to $29.8 \%$. Additionally, the selectivity to light olefins increased from $16.73 \mathrm{wt} \%$ to $23.64 \mathrm{wt} . \%$ by increasing the temperature from $260{ }^{\circ} \mathrm{C}$ to $290{ }^{\circ} \mathrm{C}$. It is known that ethylene is much more reactive than propylene or butylene, and as the most active species, the readsorption and secondary hydrogenation reactions of ethylene are much stronger when $\mathrm{H}_{2} / \mathrm{CO}$ ratio slightly increases from 1.25 to 1.51 in the spinning basket reactor. In contrast to the propylene and butylene, the selectivity of ethylene decreased by increasing the temperature, pressure, and $\mathrm{H}_{2} / \mathrm{CO}$ ratio, while increasing the space velocity caused an increase in the ethylene selectivity [68].

In another study by $\mathrm{Li}$ et al. [50], Fe-Mn bimetallic catalysts were used for the $\mathrm{CO}$ hydrogenation, and a positive effect of $\mathrm{Mn}$ on light-olefin production was observed in this study. By the addition of $\mathrm{Mn}$ to Fe catalyst $(\mathrm{Fe} / \mathrm{Mn}$ atomic ratio $=100 / 7)$, the $\mathrm{CO}$ conversion increased from $29.9 \%$ to $45.1 \%$, and selectivity to $\mathrm{C}_{2}-\mathrm{C}_{4}$ olefins increased from $17.4 \%$ to $33.2 \%$. The addition of $\mathrm{Mn}$ resulted in a higher BET surface area and pore volume, and WGS activity was improved, while oxidation of iron carbides in the FT reaction was suppressed. The surface basicity of the catalyst also increased in the presence of Mn and resulted in the higher selectivity to olefins. In the study by Liu et al. [69], a series of Mn-modified $\mathrm{Fe}_{3} \mathrm{O}_{4}$ microsphere catalysts with different Mn loadings of 0 wt.\%, 3 wt.\%, $6 \mathrm{wt} . \%$, and $12 \mathrm{wt} . \%$ were prepared by the impregnation method. The $6 \mathrm{wt} . \% \mathrm{Mn} / \mathrm{Fe}_{3} \mathrm{O}_{4}$ catalyst showed the high selectivity of $60.1 \%$ to $C_{2}-C_{4}$ olefins and the olefin to paraffin $(\mathrm{O} / \mathrm{P})$ ratio of 9.2 at the $\mathrm{CO}$ conversion of $41.5 \%$. The unmodified $\mathrm{Fe}_{3} \mathrm{O}_{4}$ catalyst reduced by syngas was mainly carburized to Hägg carbide $\left(\chi-\mathrm{Fe}_{5} \mathrm{C}_{2}\right)$. The electronic state of surface carbonaceous species was affected by the addition of $\mathrm{Mn}$ and resulted in the formation of another phase of iron carbide $\left(\theta-\mathrm{Fe}_{3} \mathrm{C}\right)$, which can improve the olefin production by only enhancing the carburization of the catalysts and reducing the diffusion resistance of products. The highest activity of the $6 \mathrm{wt} . \% \mathrm{Mn} / \mathrm{Fe}_{3} \mathrm{O}_{4}$ catalyst is attributed to the highest content of $\theta-\mathrm{Fe}_{3} \mathrm{C}$ species in this catalyst, which decreased by the further increase in the Mn content to $12 \mathrm{wt}$ \%. The content of Hägg carbide continuously decreased by increasing the Mn content.

Mirzaei et al. [70] prepared a series of Fe-Mn catalysts by employing the coprecipitation method, and their catalytic activities in FTO reaction were examined in a fixed-bed stainless steel microreactor. The effects of different parameters such as $\mathrm{pH}$ of precipitation, aging time, and $\mathrm{Fe} / \mathrm{Mn}$ ratio were investigated. To evaluate the effect of aging time, a series of $\mathrm{Fe} / \mathrm{Mn}$ catalysts, with the $\mathrm{Fe} / \mathrm{Mn}$ molar ratio of $1 / 1$, at $70{ }^{\circ} \mathrm{C}$, and $\mathrm{pH}=8.3$, were prepared by coprecipitation method with different aging times (0-300 min). The detected actual phase in these catalysts are shown in Table 3. The FeO, $\mathrm{MnO}$, and iron carbide phases which are active in FTS were detected in all samples. The iron carbide is the active phase 
for $\mathrm{CO}$ hydrogenation, and $\mathrm{MnO}$ is the active phase for olefin production. It was found that the catalyst aged for $180 \mathrm{~min}$ had the optimum catalytic activity for CO hydrogenation.

Table 3. Different identified phases in the calcined catalysts with different aging times [70].

\begin{tabular}{ll}
\hline Aging Time (min) & Phases \\
\hline 0 & $\mathrm{MnO}$ (cubic), $\mathrm{FeO}$ (cubic), $\mathrm{Fe}_{2} \mathrm{C}$ (orthorhombic), $\mathrm{CFe}_{2.5}$ (monoclinic) \\
30 & $\mathrm{MnO}$ (cubic), $\mathrm{FeO}$ (cubic), $\mathrm{Fe}_{2} \mathrm{C}$ (orthorhombic), $\mathrm{CFe}_{2.5}$ (monoclinic) \\
60 & $\mathrm{MnO}$ (cubic), $\mathrm{FeO}$ (cubic), $\mathrm{Fe}_{2} \mathrm{C}$ (orthorhombic), $\mathrm{CFe}_{2.5}$ (monoclinic) \\
120 & $\mathrm{MnO}$ (cubic), $\mathrm{FeO}$ (cubic), $\mathrm{CFe}_{2.5}$ (monoclinic) \\
180 & $\mathrm{MnO}$ (cubic), $\mathrm{FeO}$ (cubic), $\mathrm{CFe}_{2.5}$ (monoclinic), $\mathrm{Fe}$ (cubic) \\
300 & $\mathrm{MnO}$ (cubic), $\mathrm{FeO}$ (cubic), $\mathrm{CFe}_{2.5}$ (monoclinic) \\
\hline
\end{tabular}

The effect of $\mathrm{pH}$ was also investigated for the $\mathrm{Fe} / \mathrm{Mn}$ catalyst $\left(\mathrm{Fe} / \mathrm{Mn}=1 / 1,70{ }^{\circ} \mathrm{C}, 3 \mathrm{~h}\right.$ aging time), using $\mathrm{pH}$ in the range of 6.3 to 10.3 [70]. The catalytic performances in the FT reaction (Figure $5 \mathrm{~A}$ ) showed that the highest $\mathrm{CO}$ conversion and $\mathrm{C}_{2}-\mathrm{C}_{4}$ olefins were obtained at a $\mathrm{pH}$ of 8.3. Different phases, including $\mathrm{MnO}, \mathrm{FeO}$, and $\mathrm{CFe}_{2.5}$ were identified in this catalyst, and all these oxidic and carbide phases are active in the FT reaction. The effect of the Fe/Mn ratio was also studied as an important parameter (Figure $5 \mathrm{~B}$ ). The catalysts were prepared at $70^{\circ} \mathrm{C}, \mathrm{pH}=8.3$, aging time of $3 \mathrm{~h}$, with the $\mathrm{Fe} / \mathrm{Mn}$ ratios varying from $100 \%$ Fe to $100 \% \mathrm{Mn}$. The catalyst with the Fe/Mn molar ratio of $1 / 1$ revealed the highest $\mathrm{CO}$ conversion and the lowest methane formation. The XRD patterns of the calcined samples revealed that the $100 \%$ Fe catalyst contained $\mathrm{Fe}_{2} \mathrm{O}_{3}$ (rhombohedral) phase and the $100 \% \mathrm{Mn}$ catalyst contained $\mathrm{Mn}_{2} \mathrm{O}_{3}$ (cubic) phase, while for the other samples, different phases, including both $\mathrm{Mn}_{2} \mathrm{O}_{3}$ (cubic) and $\mathrm{Fe}_{2} \mathrm{O}_{3}$ (rhombohedral), were identified. The $\mathrm{Fe} / \mathrm{Mn}(\mathrm{Fe} / \mathrm{Mn}=1 / 1)$ catalyst, after the FT reaction, was characterized by XRD to identify the formed phases, and $\mathrm{MnO}$ (cubic), $\mathrm{FeO}$ (cubic), and $\mathrm{CFe}_{2.5}$ (monoclinic) phases were detected in this sample [70].

The bimetallic Fe/Co catalysts for the FTO process were studied by Mirzaei et al. [71,72]. They prepared a series of Fe/Co catalysts with different preparation conditions and found that the highest selectivity to light olefins $\left(C_{2}+C_{3}\right)$ was obtained for the over $40 \% \mathrm{Fe} / 60 \% \mathrm{Co}$ catalyst under reaction conditions $\left(450{ }^{\circ} \mathrm{C}, \mathrm{H}_{2} / \mathrm{CO}=4 / 1, \mathrm{GHSV}=5400 \mathrm{~h}^{-1}\right)$ (Figure S2). The $\mathrm{Co}_{3} \mathrm{O}_{4}$ (cubic), $\mathrm{CoFe}_{2} \mathrm{O}_{4}$ (cubic), and $\mathrm{Fe}_{2} \mathrm{O}_{3}$ (cubic and tetragonal) phases were identified in the calcined $40 \% \mathrm{Fe} / 60 \%$ Co catalyst. After the FTO reaction, different phases, including metallic iron (cubic), iron carbides in the forms of $\mathrm{Fe}_{7} \mathrm{C}_{3}$ (hexagonal), $\mathrm{Fe}_{3} \mathrm{C}$ (orthorhombic), and $\mathrm{Fe}_{2} \mathrm{C}$ (monoclinic), and cobalt carbide $\left(\mathrm{CoC}_{2}\right)$ were identified in the $40 \% \mathrm{Fe} / 60 \%$ Co catalyst.

\subsection{Supported Iron-Based Catalysts}

In order to ensure efficiency in both slurry- and fixed-bed reactors, the catalyst particles should be resistant to crushing, fracturing, and attrition. One of the main problems associated with using an unsupported iron catalyst is their physical degradation and formation of catalyst fines, which can plug the fixed-bed reactor and generate a large pressure gradient or cannot be easily separated from the catalyst-containing slurry $[30,73]$. At high reaction temperature, which is required for the production of lighter hydrocarbons, bulk iron catalysts are mechanically unstable, and undesired Boudouard reaction $\left(2 \mathrm{CO}(\mathrm{g}) \rightarrow \mathrm{C}(\mathrm{s})+\mathrm{CO}_{2}(\mathrm{~g})\right)$ may take place, and deposition of carbon can block the active sites and results in the fragmentation of the particles in bulk iron catalysts. The accumulation of inactive, graphitic carbon on the carbide particle surfaces, which are the active sites for FT reaction, inhibits the FT reaction and reduces the activity [74]. 

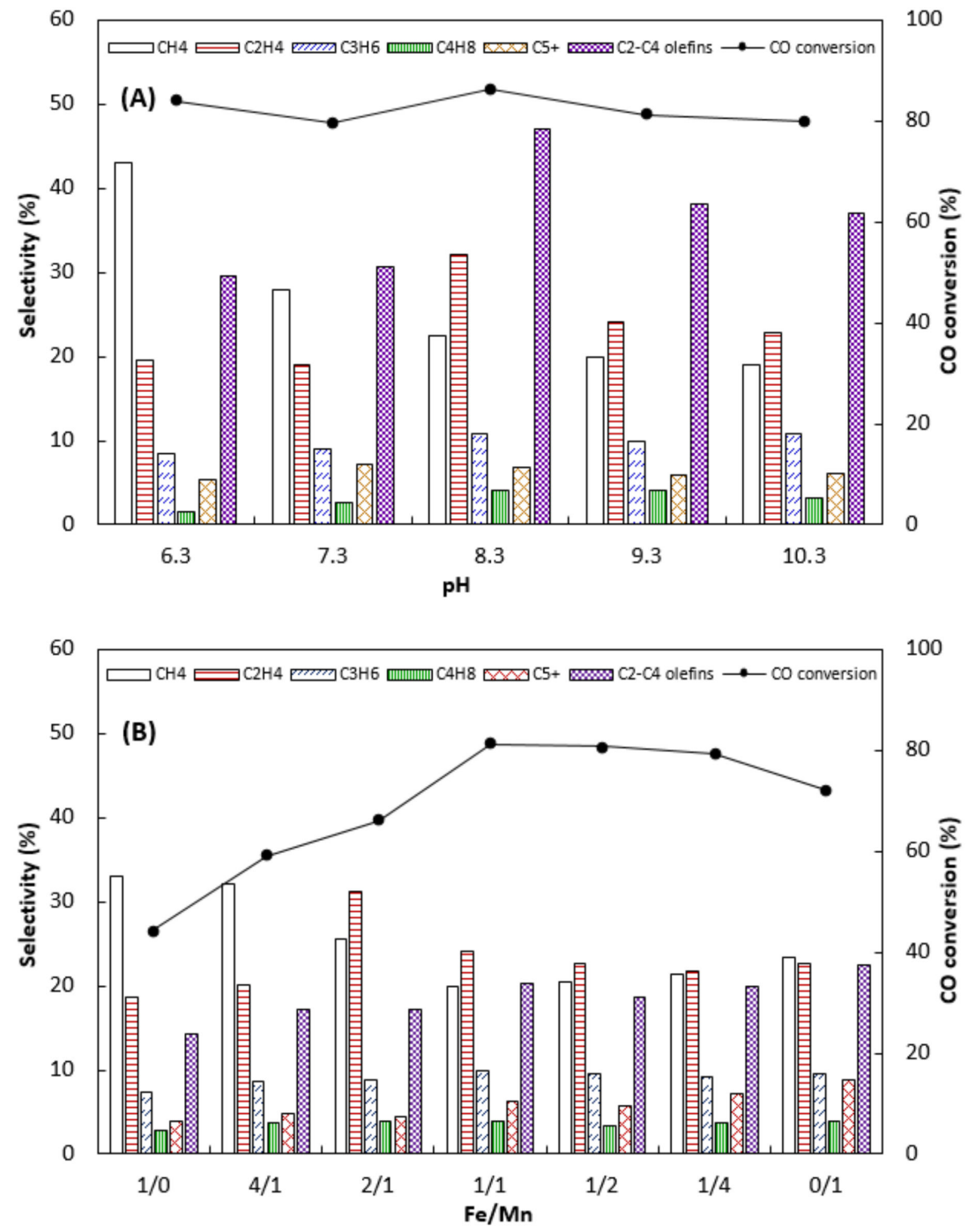

Figure 5. Effect of (A) precipitation $\mathrm{pH}$, and (B) Fe/Mn molar ratio on the catalytic performance. Reduction: $\mathrm{N}_{2} / \mathrm{H}_{2}=1,30 \mathrm{~mL} / \mathrm{min}, 400{ }^{\circ} \mathrm{C}, 6 \mathrm{~h}$; Reaction: $400^{\circ} \mathrm{C}, 1 \mathrm{bar}, \mathrm{H}_{2} / \mathrm{CO}=2$. Reproduced from ref. [70].

The use of a support affects the catalytic performance and product distributions. Metal complexes or clusters are used on different types of supports such as zeolites, alumina, or silica. Supports affect the molecular weight distribution, not only by their basic or acidic properties but also by their ability for the stabilization of metal dispersions and by their geometric properties. Supports can act as a binder and interact with supports and metal oxides. These properties of supports can affect the catalyst's activity, selectivity, product distribution, and lifetime. The chemical properties of the support may affect the catalytic performance. The strength of metal-support interaction (MSI) can significantly affect the dispersion of active metals, reducibility of the metal oxides, and catalysts lifetime can be significantly affected by the strength of metal-support interaction (MSI). A weak MSI leads to the formation of larger metal particles, which can be reduced easily and consequently enhances the catalyst activity and selectivity. In addition, MSI that are weak (e.g., Fe catalyst supported on activated carbon) may result in the fast deactivation due to the iron sintering and formation of graphitic carbon. On the other hand, too strong MSI leads to the formation of smaller metal particles and decreases the reducibility of metal particles. It also results in the formation of iron-support mixed compounds such as aluminate or 
silicate, which are very difficult to reduce or carbidize and do not create any active sites for high-temperature FT reaction; therefore, decreasing the catalytic activity [25,31,75].

Several types of materials such as silica, alumina, titania, magnesia, zirconia, zeolites, carbonaceous materials, and silicon carbide have been used as support for catalysts [73,75-80]. The catalyst activity can be enhanced by deploying support materials with weak MSI. The selectivity to lower olefins can also be improved by the addition of promoters such as $\mathrm{K}$ or Mn [81]. In general, iron catalysts supported on a porous support can enhance the mechanical stability and increase the catalyst activity. During the FT reaction, support can help to retain highly dispersed iron in a carbidized state. The product selectivity of the supported iron catalysts can be modified using promoters.

\subsubsection{Silica Supported Catalysts}

O'Brien et al. [73] reported that iron-based catalysts are more productive than a similar mass of cobalt-based catalysts for $\mathrm{CO}$ conversions by up to $50 \%$. The unsupported iron catalyst disintegrated after $24 \mathrm{~h}$ of reaction, while the integrity of the catalysts supported on different materials (alumina, silica, and magnesium aluminate) was preserved during hundreds of hours of FT reaction in the slurry reactor. Amongst different supports in this study, the silica-supported catalyst showed the lowest disintegration in this reaction [73]. Zhang et al. [82] compared the physico-chemical properties and the catalytic activity of the core-shell structure Fe@Si catalyst with the catalysts prepared by the conventional methods of impregnation $(\mathrm{Fe} / \mathrm{Si}$ ) and precipitation (Fe-Si). In this study, a two-step process (including solvothermal synthesis and the Stöber method) was used for the synthesis of the Fe@Si catalyst. The core-shell Fe@Si catalysts, with a unique structure, can prevent the agglomeration of the active metals. Sintering of the iron particles is a common phenomenon in the $\mathrm{SiO}_{2}$-supported iron catalysts prepared by impregnation or precipitation method for FT reaction. Due to the confining effect of the $\mathrm{SiO}_{2}$ shell, iron particles sintering would be decreased in core-shell structure Fe@Si catalysts. However, the $\mathrm{Fe}-\mathrm{SiO}_{2}$ interaction in the core-shell structure Fe@Si catalyst could affect the metal dispersion and reduction behavior of the catalyst. The XRD analysis of the catalysts activated by syngas $\left(\mathrm{H}_{2} / \mathrm{CO}=2\right)$ at $350{ }^{\circ} \mathrm{C}$ for $24 \mathrm{~h}$ (Figure 6A) confirmed the formation of iron carbides on both Fe@Si and $\mathrm{Fe} / \mathrm{Si}$ catalysts, while due to the stronger $\mathrm{Fe}-\mathrm{SiO}_{2}$ interaction in $\mathrm{Fe}-\mathrm{Si}$ catalyst, the peaks were not very obvious, and this strong MSI caused a decrease in the degree of reduction and carburization in Fe-Si catalyst. It was suggested that the synthesis of the core-shell structure catalysts with larger pore size and thin $\mathrm{SiO}_{2}$ shell might be a promising method to overcome these drawbacks of the catalysts. It has been frequently reported that the iron carbides are the active phase for iron-based catalysts in FT reaction, and it is a linear correlation between the catalyst activity and carbide content of the catalyst. The iron carbides content of the catalysts after activation were in the following order: $\mathrm{Fe} / \mathrm{Si}(55.7 \%)>$ Fe@Si $(52.01 \%)>$ Fe-Si $(29.67 \%)$, and as expected, the catalyst activity also followed the same trend.

The XRD patterns of the spent catalysts after the FT reaction at $280{ }^{\circ} \mathrm{C}, 2.0 \mathrm{MPa}$, and the $\mathrm{H}_{2} / \mathrm{CO}=2$ (Figure $6 \mathrm{~B}$ ) showed that the peaks belonging to iron carbides were strengthened in the Fe-Si catalyst, while in the other two catalysts their intensities decreased, the peaks of $\mathrm{Fe}_{3} \mathrm{O}_{4}$ were more evident in these catalysts, and iron carbides were oxidized during the FT reaction. Further carburization of $\mathrm{Fe}_{3} \mathrm{O}_{4}$, not carburized during the activation step, can result in the formation of more iron carbides, while at the same time, the available iron carbides can be oxidized by water to give $\mathrm{Fe}_{3} \mathrm{O}_{4}$ [83]. These two opposite processes are mainly related to the $\mathrm{Fe}-\mathrm{SiO}_{2}$ interaction, initial iron carbide content, and the process conditions $[82,84]$. 

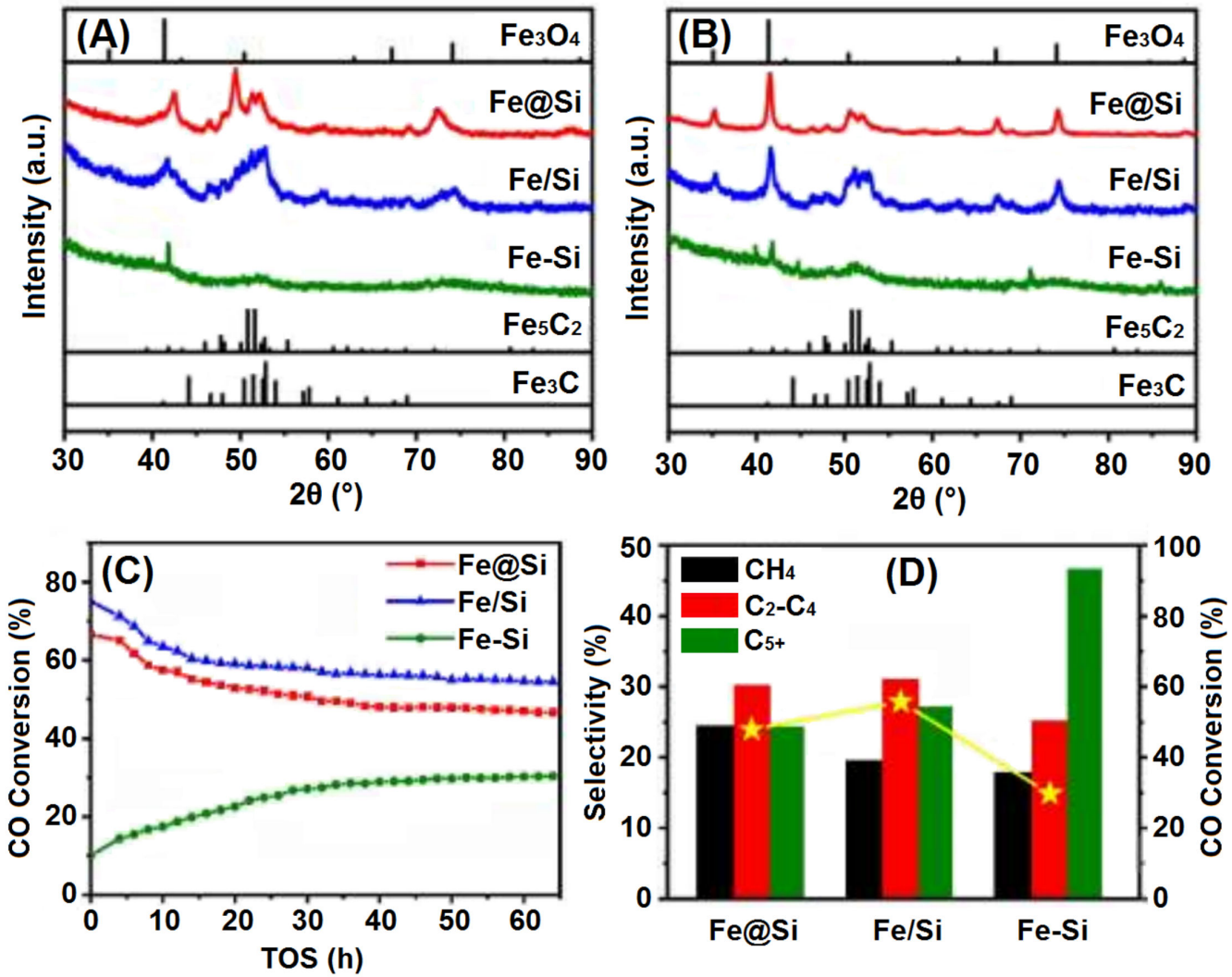

Figure 6. XRD patterns of Fe@Si, Fe/Si and Fe-Si catalysts (A) after activation, (B) after FT reaction, (C) stability test of Fe@Si, Fe/Si and Fe-Si catalysts at $280^{\circ} \mathrm{C}, 2.0 \mathrm{MPa}$, (D) Comparison of hydrocarbon products distribution [82].

The high initial iron carbides content in Fe/Si and Fe@Si catalysts ensures high CO conversion at the beginning of the reaction and leads to the higher $\mathrm{H}_{2} \mathrm{O}$ partial pressure (Figure 6C). Subsequently, oxidation of iron carbides outperformed the further carburization of $\mathrm{Fe}_{3} \mathrm{O}_{4}$, and therefore, the content of iron carbides in the spent catalysts decreased to $41.57 \%$ and $49.20 \%$ for Fe@Si and Fe/Si catalysts, respectively. This process caused a gradual decrease in the catalyst activity of Fe@Si and Fe/Si catalysts during the FT reaction. The sintering of iron species in $\mathrm{Fe} / \mathrm{Si}$ catalyst is another reason for decreasing the catalyst activity. The Fe-Si catalyst with the lowest carbide content showed the lowest initial activity, while due to the further carburization of $\mathrm{Fe}_{3} \mathrm{O}_{4}$ during the reaction and increasing the carbide content (from $29.67 \%$ to $34.78 \%$ ) as an active phase in this catalyst, the CO conversion increased by increasing the reaction time [82]. The product distribution over these catalysts is shown in Figure 6D. The Fe@Si catalyst showed the highest selectivity to methane, while the lowest selectivity to methane and the highest selectivity to $\mathrm{C}_{5+}$ hydrocarbons were observed for the Fe-Si catalysts. The smaller iron particle size led to the formation of heavier hydrocarbons, which could be due to the enhanced $\mathrm{Fe}-\mathrm{C}$ bond that augmented the chain growth reaction [85]. The higher iron dispersion and smaller particle size of iron in Fe-Si catalyst than Fe@Si and Fe/Si catalysts is the reason for its higher selectivity to heavier hydrocarbons. For the Fe@Si catalyst, desorption of the hydrocarbon products might be hindered due to the confinement effect of the $\mathrm{SiO}_{2}$ shell, and the trapped hydrocarbons might go through the secondary reaction, and the product distribution shifts to the lower hydrocarbons over Fe@Si catalyst. The presence of $\mathrm{SiO}_{2}$ shell in Fe@Si catalyst can increase the $\mathrm{H}_{2} \mathrm{O}$ partial pressure, enhance the WGS reaction, and lead to higher $\mathrm{CO}_{2}$ formation than the Fe/Si catalyst [82].

Mogorosi et al. [86] reported that the iron carbides are the main iron phases in the spent Fe/Si catalysts. The iron phases of the calcined, reduced, and spent catalysts were 
determined using X-ray diffraction analysis (XRD) (Table S3). After the reduction of catalysts using hydrogen at $350{ }^{\circ} \mathrm{C}$ for $16 \mathrm{~h}, \mathrm{Fe}_{2} \mathrm{O}_{3}$ (hematite $\left(\alpha-\mathrm{Fe}_{2} \mathrm{O}_{3}\right)$ and maghemite $\left.\left(\gamma-\mathrm{Fe}_{2} \mathrm{O}_{3}\right)\right)$ were reduced to magnetite and metallic iron $\left(\mathrm{Fe}_{2} \mathrm{O}_{3} \rightarrow \mathrm{Fe}_{3} \mathrm{O}_{4} \rightarrow \mathrm{Fe}\right)$. The reduction of hematite occurred at a higher temperature than that of magnetite, while the reduction of magnetite to metallic iron did not affect by the origin of the magnetite phase. $\mathrm{Fe}_{2} \mathrm{O}_{3}$ was also reduced to wüstite $(\mathrm{FeO})$ at temperatures above $570{ }^{\circ} \mathrm{C}$, where the $\mathrm{FeO}$ phase is stable against disproportionation into $\mathrm{Fe}_{3} \mathrm{O}_{4}$ and $\mathrm{Fe}\left(4 \mathrm{FeO} \rightarrow \mathrm{Fe}_{3} \mathrm{O}_{4}+\mathrm{Fe}\right)$. The disproportionation of wüstite is kinetically possible at temperatures above $200{ }^{\circ} \mathrm{C}$ in an inert atmosphere and above $150{ }^{\circ} \mathrm{C}$ in a hydrogen-containing atmosphere [86]. The spent iron catalyst $(\mathrm{Si} / \mathrm{Fe}=0)$ contained only Hägg carbide $\left(\chi-\mathrm{Fe}_{5} \mathrm{C}_{2}\right)$, as a common iron carbide phase in iron-based FT catalysts, while the silicon-containing catalysts contained both Hägg carbide and hexagonal iron carbides $\left(\varepsilon-\mathrm{Fe}_{2} \mathrm{C}\right)$. The $\alpha$-Fe in the reduced catalysts might be transformed into Hägg carbide after exposing to syngas during the FT reaction. The lower content of formed $\chi-\mathrm{Fe}_{5} \mathrm{C}_{2}$ in the spent catalysts than the $\alpha$-Fe content in the reduced catalysts indicated that the $\alpha$-Fe was transformed into either $\chi-\mathrm{Fe}_{5} \mathrm{C}_{2}$ or $\varepsilon-\mathrm{Fe}_{2} \mathrm{C}$ carbides (Figure 7). It was also observed that the crystallite size of $\chi-\mathrm{Fe}_{5} \mathrm{C}_{2}$ in the spent catalyst was smaller than the original $\alpha$-Fe crystallites, indicating the crystallite break-up during the carburization because of strain within the crystal introduced by diffusion of carbon into the structure [86]. Carbides with octahedral interstices (O-carbides), such as $\varepsilon-\mathrm{Fe}_{2} \mathrm{C}$ (except $\eta-\mathrm{Fe}_{2} \mathrm{C}$ ), are enthalpically more stable than the carbides with trigonal bipyramidal interstices (TP-carbides), such as $x-\mathrm{Fe}_{5} \mathrm{C}_{2}$. The surface modification of an iron oxide catalyst by the addition of $\mathrm{Si}$ resulted in the formation of $\varepsilon-\mathrm{Fe}_{2} \mathrm{C}$, which is thermodynamically favored, and it became kinetically favored due to a retardation of the carbon diffusion into the iron matrix, thereby allowing for sufficient time for the lattice expansion and formation of $\mathrm{O}$-carbides. The $\varepsilon-\mathrm{Fe}_{2} \mathrm{C}$ is formed from $\alpha$-Fe and the silicon stabilized $\mathrm{FeO}$ phase. Some of the silicon ligands might undergo hydrolysis with the water produced during the FT reaction and could form amorphous silica.

In the study by Chang e al. [87], the role of different types of iron carbides $\left(\varepsilon-\mathrm{Fe}_{2} \mathrm{C}\right.$, $\chi-\mathrm{Fe}_{5} \mathrm{C}_{2}$, and $\mathrm{Fe}_{7} \mathrm{C}_{3}$ ) on the catalytic performance of the $\mathrm{Fe} / \mathrm{SiO}_{2}$ was investigated. Changing the reducing agent resulted in the formation of different carbide phases of $\chi-\mathrm{Fe}_{5} \mathrm{C}_{2}+\varepsilon-\mathrm{Fe}_{2} \mathrm{C}$, $\chi-\mathrm{Fe}_{5} \mathrm{C}_{2}+\mathrm{Fe}_{7} \mathrm{C}_{3}$, and $\chi-\mathrm{Fe}_{5} \mathrm{C}_{2}$ when $\mathrm{H}_{2}, \mathrm{CO}$, and syngas were used as reducing agents, respectively. The catalyst activities were evaluated at $260{ }^{\circ} \mathrm{C}, 3 \mathrm{MPa}$, and $\mathrm{H}_{2} / \mathrm{CO}$ of 2 , and the results were in the following order: $\mathrm{Fe} / \mathrm{SiO}_{2}(\mathrm{CO}$ activated $)>\mathrm{Fe} / \mathrm{SiO}_{2}\left(\mathrm{H}_{2}\right.$ activated) $>\mathrm{Fe} / \mathrm{SiO}_{2}$ (syngas activated). The catalytic activity is related to the particle size, the carbide phase and its contents. The catalyst activity could be enhanced in the presence of $\mathrm{Fe}_{7} \mathrm{C}_{3}$, while the presence of $\varepsilon-\mathrm{Fe}_{2} \mathrm{C}$ phase led to the higher selectivity to $\mathrm{C}_{5+}$ and lower methane formation.

The catalytic performance of iron catalysts can also be affected by the textural properties of the support. The effect of pore size on the catalytic performance of iron catalysts (10 wt.\%) supported on mesoporous silicas with different pore sizes $(2.8,5.2,7.2,7.7$, and $9.2 \mathrm{~nm}$ ) in FT reaction was studied by Cheng et al. [75]. The commercial catalysts with larger pores of 17.5 and $50 \mathrm{~nm}$ were also used in this study. High iron dispersion with a low degree of carbidization during the FT reaction at high temperature was observed for the catalysts with smaller pore sizes, while the larger pore size led to the formation of larger iron particles with a higher degree of carbidization. The catalytic activity could be affected by the presence of Hägg iron carbide $\left(\chi-\mathrm{Fe}_{5} \mathrm{C}_{2}\right)$, which depends on the degree of iron carbidization. The crystallite size of the iron particles also followed the same trend as the pore size of supports, and the smaller particles were observed on the support with a smaller pore size. The stronger MSI facilitates the formation of iron silicate species, which are difficult to reduce and increase the reduction temperature. The fraction of iron silicate in the catalysts with smaller pores and particle sizes is much higher than those in the catalysts with larger pores and particle sizes. According to Zhang et al. [88], the phase analysis of the silica-supported iron catalyst showed that the main phase in the fresh supported catalyst was iron oxide mixtures (hematite and maghemite), and in the catalyst reduced under 
hydrogen, the main phases were wüstite and iron (II) silicate $\left(\mathrm{Fe}_{2} \mathrm{SiO}_{4}\right)$. It was observed that the silica-supported iron catalyst had a lower $\mathrm{CO}$ conversion and higher selectivity to light hydrocarbons $\left(\mathrm{C}_{1}-\mathrm{C}_{4}\right)$ than the unsupported catalyst.

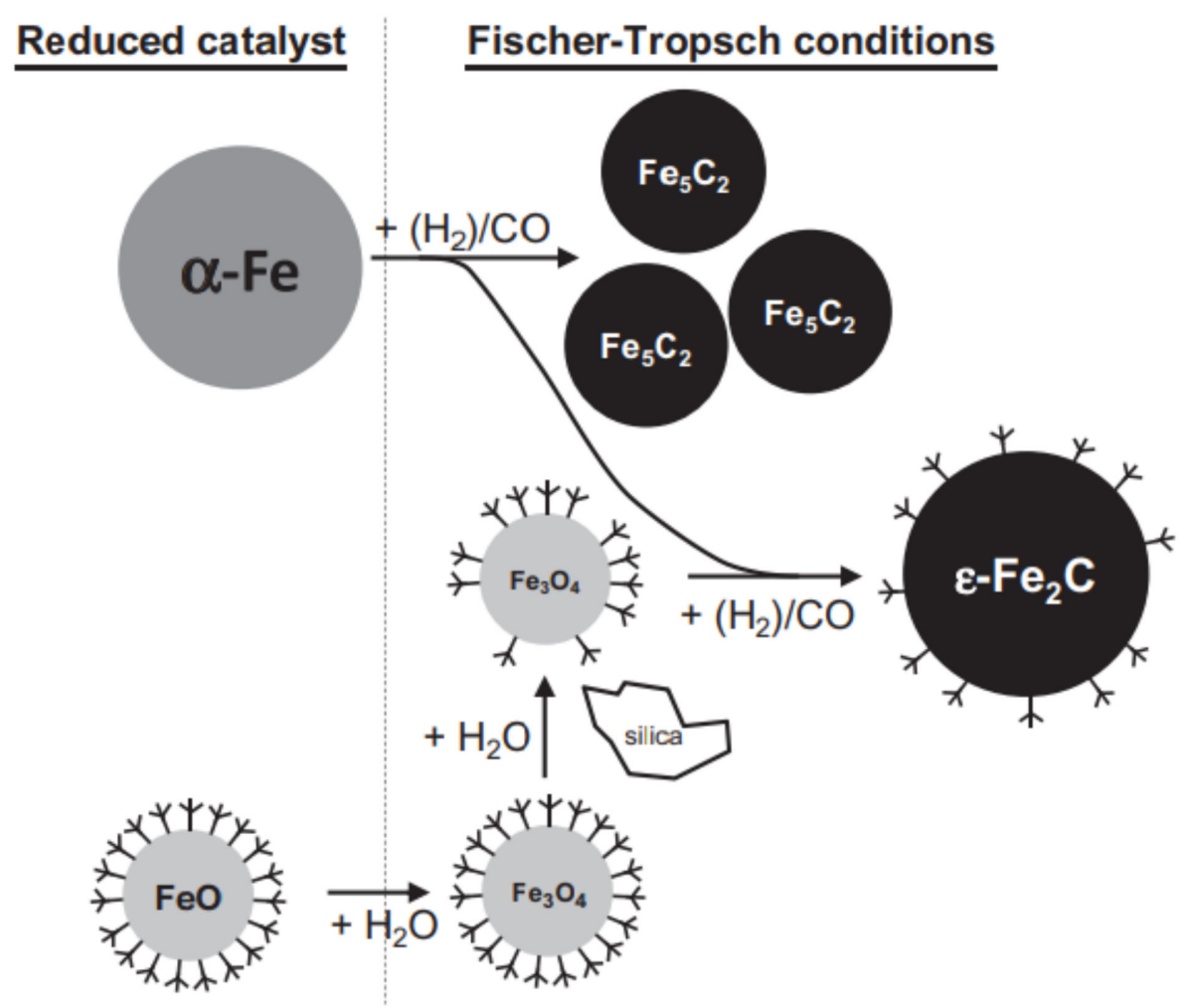

Figure 7. Transformation of $\alpha$-Fe and FeO stabilized by silicate surface ligands during the FischerTropsch synthesis [86].

The size of iron carbide in the spent catalysts also slightly increased. A reduction of the catalyst by $\mathrm{CO}$ increased the formation of Hägg iron carbide. A higher FT reaction rate, selectivity to $\mathrm{C}_{5+}$ and olefins were observed over the iron catalyst with large pore size. The silica pore size affects the extent of iron carbidization. Carbidization of the larger iron particles, which are located in the support with the larger pore size, and formation of Hägg iron carbide is much easier than the carbidization of smaller iron oxide particles in smaller pore supports. Due to the lower level of iron carbidization in the catalysts supported on small pore silica, the higher metal dispersion was not favorable for the hydrogenation of carbon monoxide [75].

In supports with small pores, a smaller metal particle leads to a higher metal surface area and higher surface catalytic activity, but provides a strong reactant diffusion resistance. The support with a larger pore size improves the reducibility and diffusion of reactants and products, and it can suppress the readsorption of 1-olefins and result in the formation of heavier hydrocarbons [89]. The increased chain growth probability over the catalysts with large pore size might be due to the combination of larger pore size and larger metal particle size. The effect of pore size and iron particle size on the formation of light olefins in an FT reaction was investigated by Liu et al. [90]. The smaller metal particle size resulted in the formation of light hydrocarbons, including methane, and it was beneficial for the light olefins formation. Selectivity to light olefins decreased by increasing the iron particle size, while the catalyst with a larger pore size showed higher selectivity to light olefins. Due to the suppression of the secondary reaction of olefins, the olefin to paraffin ratio $(\mathrm{O} / \mathrm{P})$ of $\mathrm{C}_{2}-\mathrm{C}_{4}$ hydrocarbons was increased by increasing the pore size, regardless of the iron particle size. 
Alayat et al. [77] prepared a series of 15\% iron catalysts supported on silica nanospring (NS) by different methods, including impregnation (Fe/NS-I), precipitation (Fe/NS-P), and sol-gel (Fe/NS-S). The catalyst particle sizes were in the order of Fe/NS-P (10.1 nm) > $\mathrm{Fe} / \mathrm{NS}-\mathrm{I}(4.1 \mathrm{~nm})>\mathrm{Fe} / \mathrm{NS}-\mathrm{S}(1.7 \mathrm{~nm})$. The XRD and XPS analysis revealed that the phase composition of the Fe/NS catalysts was $\alpha-\mathrm{Fe}_{2} \mathrm{O}_{3} / \mathrm{NS}-\mathrm{P}, \mathrm{Fe}_{3} \mathrm{O}_{4} / \mathrm{NS}-\mathrm{S}$, and $\gamma-\mathrm{Fe}_{2} \mathrm{O}_{3} / \mathrm{NS}-\mathrm{I}$. A strong MSI was observed in the Fe/NS-S catalyst, which can considerably suppress the carburization of the catalyst. During the catalyst activation using $\mathrm{CO}$ as a reducing agent, the carburization of $\alpha-\mathrm{Fe}_{2} \mathrm{O}_{3}$ resulted in the formation of iron carbides $\left(\mathrm{Fe}_{\mathrm{x}} \mathrm{C}\right)$, which are the active phase in the FT reaction. The catalyst activation by hydrogen led to the formation of $\alpha$-Fe, and both iron carbide and $\alpha$-Fe could be formed during the activation by a mixture of $\mathrm{H}_{2}+\mathrm{CO}$ (Figure 8).

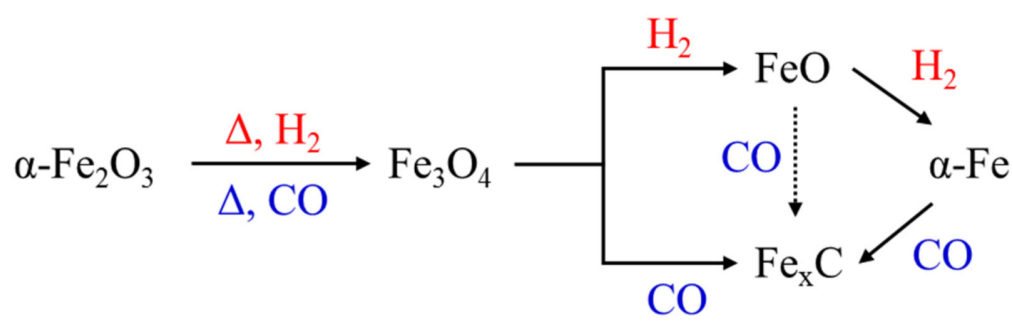

Figure 8. Schematic illustration of the activation of iron oxides using $\mathrm{H}_{2}$ or $\mathrm{CO}$ [77].

The Fe/NS-I catalyst activated using CO showed the highest activity of $76.6 \%$ with $56.9 \%$ selectivity to gasoline range $\left(\mathrm{C}_{6}-\mathrm{C}_{14}\right)$ hydrocarbons, and the branched olefins and paraffins were more favorable than n-olefins and n-paraffins over this catalyst. The lowest activity was exhibited by the Fe/NS-S catalyst with the smallest particle size and strong MSI. The main products of the reaction (in the range of $\mathrm{C}_{6}-\mathrm{C}_{14}$ hydrocarbons) for all catalysts prepared by different methods were in the following order: aromatics > branched olefins $>$ branched paraffins (including cycloalkanes).

Toncón-Leal et al. [91] reported that the mesoporous silica support (i.e., SBA-15) could be used efficiently to stabilize FT catalyst. Their results confirmed that the mesoporous structure of the support was preserved after metal loading on the surface. They also reported that the hematite $\left(\alpha-\mathrm{Fe}_{2} \mathrm{O}_{3}\right)$ was the main component of the catalyst. The effect of promoters ( $\mathrm{Li}, \mathrm{K}$, and $\mathrm{Cs}$ ) on the Fe/SBA-15 catalysts and their performance in FT reaction was investigated by Cano et al. [92]. Different iron species, including $\mathrm{Fe}_{3} \mathrm{O}_{4}, \mathrm{Fe}^{2+}$, and $\alpha-\mathrm{Fe}$, were detected in activated catalysts, and their composition varied according to the content of the promoter. In the spent catalysts, a mixture of different iron phases $\left(\mathrm{Fe}^{2+}\right.$, $\mathrm{Fe}_{3} \mathrm{O}_{4}, \chi-\mathrm{Fe}_{2} \mathrm{C}_{5}$, and $\varepsilon^{\prime}-\mathrm{Fe}_{2.2} \mathrm{C}$ ) existed inside the SBA-15 walls.

\subsubsection{Alumina Supported Catalysts}

In 1980, Barrault et al. [93] studied the effect of support properties on the catalytic activity of iron-based catalysts. It was found that catalysts with higher activity had the lower selectivity to light olefins $\left(\mathrm{C}_{2}-\mathrm{C}_{4}\right)$, and the alumina support with a higher surface area resulted in a higher selectivity to light olefins. The essential requirement for the catalysts for olefin production via FT reaction (FTO) is high selectivity to olefins, suppression of methane, and good resistance against coking under conditions that help form hydrogen deficient products [94]. The catalytic activity of alumina supported iron catalysts with different textural properties (20wt.\%Fe/Alumina) studied by Perrichon et al. [95]. The textural properties of different alumina support and the product distribution at the $\mathrm{CO}$ conversion of about $20 \%$ for the FT reaction at 15 bar and $\mathrm{H}_{2} / \mathrm{CO}$ of 1 are shown in Table 4 . 
Table 4. The textural properties and catalytic activity of alumina-supported iron catalysts [95].

\begin{tabular}{|c|c|c|c|c|c|c|}
\hline & SCS 9 & SCS 59 & SCS 350 & SAP 350 & SCM 250 & SCP 350 \\
\hline Specific area $\left(\mathrm{m}^{2} / \mathrm{g}\right)$ & 8 & 80 & 325 & 350 & 275 & 400 \\
\hline Mean pore volume $\left(\mathrm{cm}^{3} / \mathrm{g}\right)$ & 0.45 & 0.60 & 0.53 & 0.23 & 0.63 & 0.30 \\
\hline Mean pore radius $(\mathrm{nm})$ & 150 & 15 & 3.0 & 1.2 & 4.5 & 1.5 \\
\hline Reaction $\mathrm{T}\left({ }^{\circ} \mathrm{C}\right)$ & 280 & 317 & 320 & 436 & 480 & 500 \\
\hline * CO conversion $(\%)$ & 22.4 & 22.5 & 22.1 & 21.4 & 20.1 & 18.3 \\
\hline${ }^{* *} \mathrm{R}_{\mathrm{C} 1} \%$ & 25.7 & 31.0 & 29.3 & 33.9 & 26.5 & 38.1 \\
\hline $\mathrm{R}_{\mathrm{C} 2-\mathrm{C} 4} \%$ & 40.4 & 51.0 & 50.7 & 32.3 & 44.8 & 59.4 \\
\hline $\mathrm{R}_{\mathrm{C} 5+} \%$ & 33.9 & 18.0 & 20.0 & 33.8 & 28.7 & 2.5 \\
\hline Olefin in $\mathrm{C}_{2}-\mathrm{C}_{4} \%$ & 23.0 & 33.3 & 28.5 & 56.7 & 75.2 & 77.7 \\
\hline $\mathrm{CO}_{2} /\left(\mathrm{CO}_{2}+\mathrm{H}_{2} \mathrm{O}\right) \%$ & 42.0 & 54.5 & 58 & 58 & 58 & 70.0 \\
\hline Reaction $\mathrm{T}\left({ }^{\circ} \mathrm{C}\right)$ & 440 & - & 338 & - & - & - \\
\hline CO conversion $(\%)$ & 30.0 & - & 40.5 & - & - & - \\
\hline $\mathrm{R}_{\mathrm{C} 1} \%$ & 30.0 & - & 28.7 & - & - & - \\
\hline $\mathrm{R}_{\mathrm{C} 2-\mathrm{C} 4} \%$ & 28.5 & - & 42.4 & - & - & - \\
\hline $\mathrm{R}_{\mathrm{C} 5+} \%$ & 41.5 & - & 28.9 & - & - & - \\
\hline Olefin in $\mathrm{C}_{2}-\mathrm{C}_{4} \%$ & 36.0 & - & 25.9 & - & - & - \\
\hline $\mathrm{CO}_{2} /\left(\mathrm{CO}_{2}+\mathrm{H}_{2} \mathrm{O}\right) \%$ & 40.0 & - & 61.0 & - & - & - \\
\hline Reaction $\mathrm{T}\left({ }^{\circ} \mathrm{C}\right)$ & 455 & - & 359 & - & - & - \\
\hline CO conversion $(\%)$ & 35.0 & - & 59.0 & - & - & - \\
\hline $\mathrm{R}_{\mathrm{C} 1} \%$ & 33.0 & - & 31.0 & - & - & - \\
\hline $\mathrm{R}_{\mathrm{C} 2-\mathrm{C} 4} \%$ & 28.5 & - & 36.5 & - & - & - \\
\hline $\mathrm{R}_{\mathrm{C} 5+} \%$ & 38.5 & - & 32.5 & - & - & - \\
\hline Olefin in $\mathrm{C}_{2}-\mathrm{C}_{4} \%$ & 36.0 & - & 25.1 & - & - & - \\
\hline $\mathrm{CO}_{2} /\left(\mathrm{CO}_{2}+\mathrm{H}_{2} \mathrm{O}\right) \%$ & 45.0 & - & 64.0 & - & - & - \\
\hline
\end{tabular}

* Total transformation rate: $\mathrm{CO}$ conversion $(\%)=100 \times\left(\mathrm{F}_{\mathrm{CO} i}-\mathrm{F}_{\mathrm{COo}}\right) / \mathrm{F}_{\mathrm{CO} i}{ }^{* *}$ Partial product distribution $\mathrm{R}_{\mathrm{Cn}}(\%)=100 \times \mathrm{S}_{\mathrm{Cn}} /\left(100-\mathrm{S}_{\mathrm{CO}_{2}}\right)$. Selectivity of hydrocarbons: $\mathrm{S}_{\mathrm{Cn}}(\%)=100 \times\left(\mathrm{F}_{\mathrm{Cn}} \times \mathrm{n}\right) /\left(\mathrm{F}_{\mathrm{COi}}-\mathrm{F}_{\mathrm{COo}}\right), \mathrm{F}_{\mathrm{CO}}$ and $\mathrm{F}_{\mathrm{Coo}}$ are the molar flow rates of $\mathrm{CO}$ in the inlet and outlet of the reactor.

It can be seen that product selectivity was affected by the support's nature. The methane and $\mathrm{C}_{2}-\mathrm{C}_{4}$ olefin contents were directly related and followed the same trend, while the $\mathrm{C}_{2}-\mathrm{C}_{4}$ and $\mathrm{C}_{5+}$ contents did not directly relate to the other components. An evaluation of catalytic activities at different reaction temperatures revealed that the $\mathrm{CO}$ conversion increased by increasing the temperature, and product distribution shifted to the heavier hydrocarbons. However, higher temperatures are favored for olefin production, but by increasing the temperature, the olefin's content decreased for the Fe/Alumina (SCS 350). The changes in the selectivity could be attributed to the nature of the supports and their surface properties. The high selectivity to the light olefins in the SCP350-supported catalyst could be due to the weaker MSI in this catalyst, which resulted in a higher selectivity to light olefins. The reducibility of the catalysts did not significantly change following a change in the support, while the thermodesorption of the carbon monoxide was different in different catalysts. The catalyst activity was related to the $\mathrm{CO}$ dissociation rate and its binding energy to the catalyst's surface, and dissociation of carbon monoxide is considered to be a crucial step in hydrocarbon synthesis.

The effect of support properties on the catalytic activity of an iron-based catalyst was investigated by Torres Galvis et al. [30]. Iron catalysts supported on carbon nanofiber $(\mathrm{CNF}), \beta$-silicon carbide $(\beta-\mathrm{SiC}), \alpha$-alumina $\left(\alpha-\mathrm{Al}_{2} \mathrm{O}_{3}\right)$, conventional high surface area $\mathrm{SiO}_{2}$ and $\gamma-\mathrm{Al}_{2} \mathrm{O}_{3}$, and three bulk iron catalysts (Bulk Fe, Fe-Ti-Zn-K, Fe-Cu-K-SiO${ }_{2}$ ) were also used in this study. Iron loading, the average crystallite size of iron oxides, the crystalline phase of the fresh and spent catalysts, and their catalytic performances were evaluated. The iron phase of the fresh and spent catalysts was analyzed using Mössbauer spectroscopy. In all fresh catalysts, iron existed in the form of hematite $\left(\alpha-\mathrm{Fe}_{2} \mathrm{O}_{3}\right)$, and the particle sizes of supported catalysts were less than $13.5 \mathrm{~nm}$, while the bulk iron catalysts were composed of large $\mathrm{Fe}_{2} \mathrm{O}_{3}$ particles. 
The presence of a high amount of superparamagnetic (SPM) nanoparticles in Fe/CNF, $\mathrm{Fe} / \gamma-\mathrm{Al}_{2} \mathrm{O}_{3}$, and $\mathrm{Fe} / \mathrm{SiO}_{2}$ is attributed to the high dispersion of iron on these supports. As mentioned earlier, the high yield of lower olefins and minimum methane formation are the main requirements for the FTO catalyst. After $64 \mathrm{~h}$ of reaction, the $\mathrm{Fe} / \gamma-\mathrm{Al}_{2} \mathrm{O}_{3}$ and $\mathrm{Fe} / \mathrm{SiO}_{2}$ showed the lowest catalytic activity. The Mössbauer spectroscopy analysis of these catalysts after $15 \mathrm{~h}$ of reaction at 1 bar showed that they did not contain any iron carbides. The nature of iron phases was related to the properties of the supports, and the presence of $\mathrm{Fe}_{\mathrm{x}} \mathrm{C}_{\mathrm{y}}$ iron carbides could enhance the catalytic activity. The $\mathrm{Fe} / \alpha-\mathrm{Al}_{2} \mathrm{O}_{3}$ showed a slight decrease after the initial increase in activity, which could be due to the gradual decrease in methane formation, while the olefin selectivity was increased slightly during the reaction. Most of the catalysts showed $\mathrm{CO}$ conversion in the range of $77 \%$ to $88 \%$, while the $\mathrm{Fe} / \gamma-\mathrm{Al}_{2} \mathrm{O}_{3}$ catalyst showed a low $\mathrm{CO}$ conversion of $10 \%$. Promoted bulk iron catalysts with weak MSI showed high activity and selectivity to light olefins. The high $\mathrm{CO}$ conversion, high selectivity to light olefins, and low methane selectivity were obtained over $\mathrm{CNF}$ and $\alpha-\mathrm{Al}_{2} \mathrm{O}_{3}$ supported catalysts, respectively [30].

The FTO process for light-olefins production has been significantly enhanced by the development of iron-based catalysts (dispersed on the supports with weak MSI) with high activity, selectivity, and stability. The effect of iron particle size on alumina-supported catalysts for FT reaction was investigated by Park et al. [78]. In this study, the iron nanoparticles $\left(\gamma-\mathrm{Fe}_{2} \mathrm{O}_{3}\right)$ were first synthesized by the solvothermal method. The $\delta-\mathrm{Al}_{2} \mathrm{O}_{3}$ support (surface area $=127 \mathrm{~m}^{2} / \mathrm{g}$ ) with the less reactive surface was prepared by the calcination of $\gamma-\mathrm{Al}_{2} \mathrm{O}_{3}$ (surface area $=350 \mathrm{~m}^{2} / \mathrm{g}$ ) at $1000{ }^{\circ} \mathrm{C}$. Then, $5 \mathrm{wt} . \% \mathrm{Fe} / \mathrm{Al}_{2} \mathrm{O}_{3}$ catalysts were prepared by impregnating pre-synthesized $\gamma-\mathrm{Fe}_{2} \mathrm{O}_{3}$ nanoparticles on $\delta-\mathrm{Al}_{2} \mathrm{O}_{3}$ support. Preparation of iron nanoparticles at different temperatures in the range of $130-250{ }^{\circ} \mathrm{C}$ resulted in the different particle sizes in the following order: Fe-250 ${ }^{\circ} \mathrm{C}(12 \mathrm{~nm})>\mathrm{Fe}-230{ }^{\circ} \mathrm{C}(9 \mathrm{~nm})>\mathrm{Fe}-200{ }^{\circ} \mathrm{C}$ $(6.1 \mathrm{~nm})>\mathrm{Fe}-180^{\circ} \mathrm{C}(4.5 \mathrm{~nm})>\mathrm{Fe}-130^{\circ} \mathrm{C}(2 \mathrm{~nm})$. The catalysts with a particle size of $6.1 \mathrm{~nm}$ revealed the highest activity in FT reaction at $300{ }^{\circ} \mathrm{C}, 10$ bar, and $\mathrm{H}_{2} / \mathrm{CO}=2$ in a fixed-bed reactor. The small iron particles had a strong MSI with a higher reduction temperature. The bigger particles with a weak MSI could be reduced easily, but the metal dispersion could be decreased for the bigger particles, and also, the $\mathrm{CO}$ adsorption decreased by increasing the iron particle size. So, a catalyst with optimum particle size is required for the FT reaction.

The product distribution of light hydrocarbons $\left(\mathrm{C}_{1}-\mathrm{C}_{6}\right)$ for the FT synthesis over an alumina-supported iron catalyst $\left(15 \mathrm{wt} . \% \mathrm{Fe} / \mathrm{Al}_{2} \mathrm{O}_{3}\right)$ in a fixed-bed reactor was investigated by Adeleke and Gnanamani [96]. It was observed that the olefin to paraffin $(\mathrm{O} / \mathrm{P})$ ratio decreased by increasing the length of the carbon chain, which could be attributed to the higher chain growth probability of the paraffins than olefins. The further growth of the surface monomers could result in the formation of long-chain paraffins during the FT reaction over the $\mathrm{Fe} / \mathrm{Al}_{2} \mathrm{O}_{3}$ catalyst. Depending on the $\mathrm{CO}$ conversion and reaction temperature during the FT reaction, $\mathrm{C}_{2}$ olefin can go through the secondary reactions by readsorption and produce paraffins or long-chain olefins.

Xing et al. [97] prepared a series of iron catalysts supported on $\mathrm{Al}_{2} \mathrm{O}_{3}$ and $\mathrm{ZnAl}_{2} \mathrm{O}_{4} \cdot \mathrm{Al}_{2} \mathrm{O}_{3}(\mathrm{x}=1,2,3)$ by incipient wetness impregnation of the support with an aqueous solution of ammonium iron citrate. Two reference catalysts were also prepared by the coprecipitation of metal nitrates (REF-a: a mixture of $15 \% \mathrm{Fe} / 85 \% \mathrm{ZnAl} \mathrm{O}_{4} \cdot 1 \mathrm{Al}_{2} \mathrm{O}_{3}$, and REF-b: $100 \% \mathrm{Fe}$ ). XRD patterns of the reduced catalysts showed that they are composed of mainly $\mathrm{Fe}^{0}, \mathrm{ZnAl}_{2} \mathrm{O}_{4}$, and $\theta-\mathrm{Al}_{2} \mathrm{O}_{3}, \alpha-\mathrm{Al}_{2} \mathrm{O}_{3}, \beta-\mathrm{Al}_{2} \mathrm{O}_{3}$ (Table S4). Catalyst REF-b (100\%Fe) showed the highest $\mathrm{CO}$ conversion due to the higher amount of iron-active sites in this catalyst than the other $15 \%$ Fe supported catalysts (Figure S3). A comparison of the CO conversion for F1 and REF-a catalysts, which have the same composition and different preparation methods, revealed that the activity of the F1 catalyst was reduced by the thermal treatment of support at $1200^{\circ} \mathrm{C}$. Compared with the REF-a catalyst, thermal treatment of the support of the $\mathrm{F} 1$ catalyst at a high temperature of $1200{ }^{\circ} \mathrm{C}$ resulted in a decrease in the total basic sites of the catalyst. Therefore, the F1 catalyst had a lower tendency to donate electrons for the dissociative $\mathrm{CO}$ activation and consequently had lower $\mathrm{CO}$ conversion 
than the REF-a catalyst. The adsorbed CO molecule on the catalyst's surface tends to accept the electrons from iron, while the adsorbed $\mathrm{H}_{2}$ (not at very low coverage) on the surface acts as an electron donor and gives an electron to iron. As shown in Figure 9A-D, the production of $\mathrm{C}_{2}-\mathrm{C}_{4}$ olefins decreased by increasing the $\mathrm{CO}$ conversion. The olefin production was enhanced by increasing the ratio of $\mathrm{Al}_{2} \mathrm{O}_{3}$ to $\mathrm{ZnAl}_{2} \mathrm{O}_{4}$ and followed the order $\mathrm{F} 3>\mathrm{F} 2>\mathrm{F} 1>\mathrm{F} \infty$. The $15 \% \mathrm{Fe} / 85 \% \mathrm{ZnAl}_{2} \mathrm{O}_{4} \cdot 3 \mathrm{Al}_{2} \mathrm{O}_{3}$ (F3) catalyst showed the highest selectivity of $58 \%$ at 20 bar and reaction temperature in the range of $400-540{ }^{\circ} \mathrm{C}$, and olefin selectivity decreased to $49 \%$ after a further increase in the reaction temperature to $470{ }^{\circ} \mathrm{C}$.
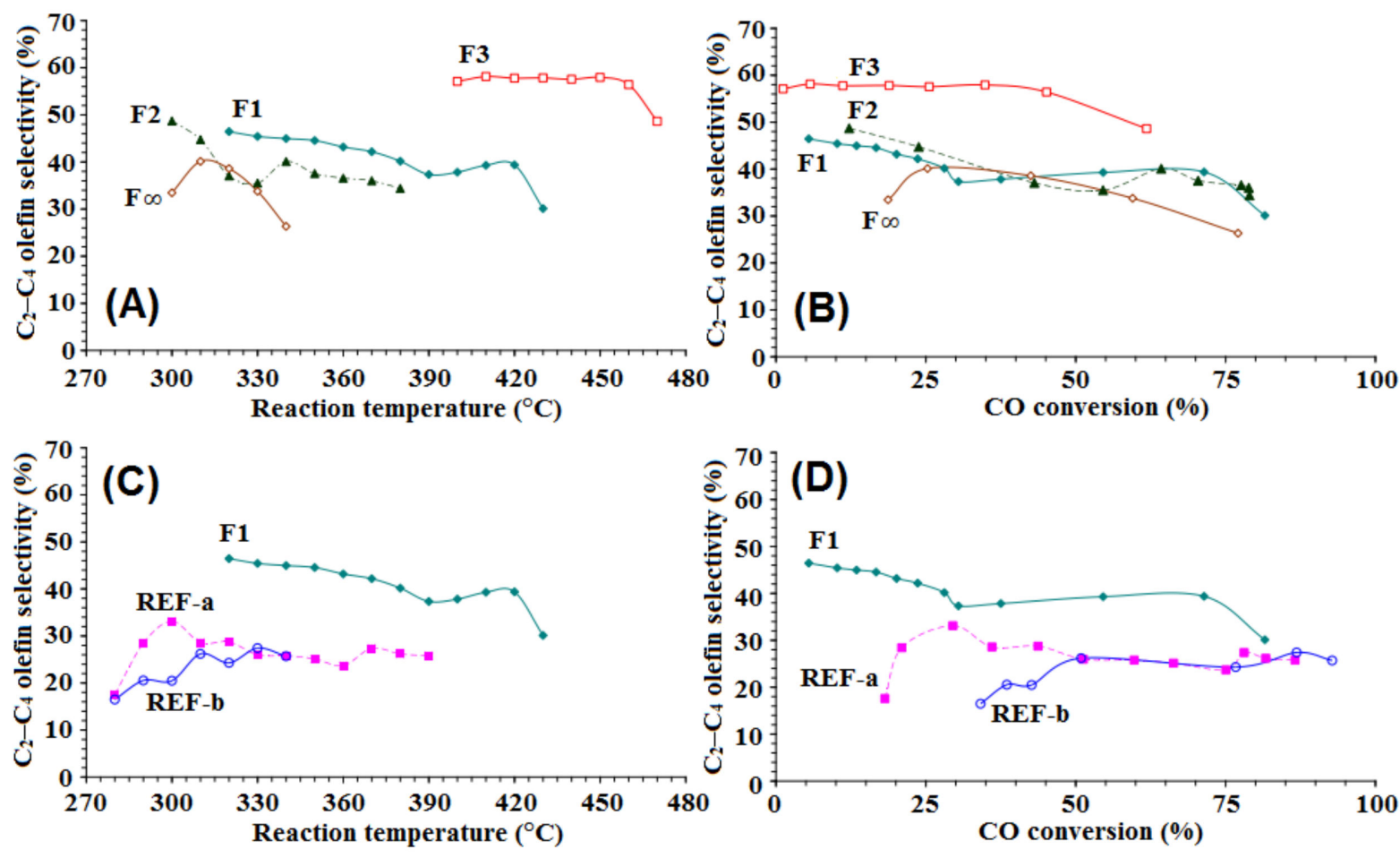

Figure 9. $\mathrm{C}_{2}-\mathrm{C}_{4}$ olefin selectivity of reduced catalysts at $(\mathrm{A}, \mathrm{C})$ different reaction temperatures and (B,D) different CO conversions [97].

The hydrogenation ability of the catalysts might become suppressed in the presence of passivated alumina phase as a solid base. The F $\infty$ catalyst with the highest amount of passivated alumina phase and the excessive amount of base resulted in an average level of $\mathrm{C}_{2}-\mathrm{C}_{4}$ olefin to paraffin ratio. However, the $\mathrm{CO}$ conversion increased from $35 \%$ to $62 \%$ by increasing the temperature from $450{ }^{\circ} \mathrm{C}$ to $470{ }^{\circ} \mathrm{C}$. A comparison between F1 and REF-a catalysts, which have the same composition but with different calcination temperatures, revealed that the formation of $\mathrm{C}_{2}-\mathrm{C}_{4}$ olefin enhanced by the thermal treatment of $\mathrm{F} 1$ at $1200{ }^{\circ} \mathrm{C}$. The REF-b catalyst, $100 \% \mathrm{Fe}$, had the highest olefin to paraffin ratio. The O/P ratio of the catalysts at about $45-55 \%$ of CO conversion were in the order of REF-b(7.8) > F3(6.6) $>\mathrm{F} \infty(3.2)>\mathrm{F} 2(2.1)>\mathrm{F} 1(1.9)>\mathrm{REF}-\mathrm{a}(1.7)$ [97]. Later, the same research group [98] prepared a series of $\mathrm{K}_{2} \mathrm{O}$ promoted catalysts, including $15 \% \mathrm{Fe} / 2 \% \mathrm{~K}_{2} \mathrm{O} / 83 \% \mathrm{ZnAl}_{2} \mathrm{O}_{4} \cdot 1 \mathrm{Al}_{2} \mathrm{O}_{3}$ (N1), $15 \% \mathrm{Fe} / 2 \% \mathrm{~K}_{2} \mathrm{O} / 83 \% \mathrm{ZnAl}_{2} \mathrm{O}_{4} \cdot 5 \mathrm{Al}_{2} \mathrm{O}_{3}$ (N5), $15 \% \mathrm{Fe} / 2 \% \mathrm{~K}_{2} \mathrm{O} / 83 \% \mathrm{Al}_{2} \mathrm{O}_{3}(\mathrm{REF} \infty)$, and $15 \% \mathrm{Fe} / 2 \% \mathrm{~K}_{2} \mathrm{O} / 83 \% \mathrm{ZnAl}_{2} \mathrm{O}_{4}$ (REF0). According to Dry et al. [99], $\mathrm{K}_{2} \mathrm{O}$ is a strong base, and bases tend to give electrons to the neighboring iron atoms and enhance the electron emission; and adsorbed $\mathrm{CO}$ on the surface of the catalyst tends to accept electrons from iron. Therefore, the presence of $\mathrm{K}_{2} \mathrm{O}$ can strengthen the $\mathrm{Fe}-\mathrm{C}$ bond and reduce the possibility of hydrogenation. At the reaction pressure of $20 \mathrm{bar}$ and a $\mathrm{CO}$ conversion of $35 \%$ over the $\mathrm{N} 1$ catalyst, the $\mathrm{O} / \mathrm{P}$ ratios of $9.8,17.7$, and 13.0 were obtained for $\mathrm{C}_{2}, \mathrm{C}_{3}$, and $\mathrm{C}_{4}$ fractions, respectively, which are significantly higher than the $\mathrm{O} / \mathrm{P}$ ratio of the catalyst without $\mathrm{K}_{2} \mathrm{O}$ promotion $(\mathrm{O} / \mathrm{P}=1.9)$. The highest $\mathrm{C}_{2}-\mathrm{C}_{4}$ olefin selectivity of $52.1 \%$ was obtained over the 
$\mathrm{N} 1$ catalyst at $340{ }^{\circ} \mathrm{C}$ and $\mathrm{CO}$ conversion of $38.3 \%$, and hydrogenation of olefins to paraffins was successfully suppressed, while the content of olefins in the fractions of $\mathrm{C}_{2}, \mathrm{C}_{3}$, and $\mathrm{C}_{4}$ hydrocarbons reached ultra-high values of $90.7 \%, 94.7 \%$, and $92.9 \%$, respectively [98]. In another study by Liu et al. [100], the $15 \% \mathrm{Fe} / 2 \% \mathrm{~K}_{2} \mathrm{O} / 83 \% \mathrm{ZnAl}_{2} \mathrm{O}_{4} \cdot 3 \mathrm{Al}_{2} \mathrm{O}_{3}$ catalyst exhibited the high $\mathrm{C}_{2}-\mathrm{C}_{4}$ olefin selectivity of $64.4 \%$ at $360{ }^{\circ} \mathrm{C} 20$ bar, and $\mathrm{CO}$ conversion of $15.2 \%$. The content of olefins in $\mathrm{C}_{2}, \mathrm{C}_{3}$, and $\mathrm{C}_{4}$ fractions were $88 \%, 92 \%$, and $89 \%$, respectively.

\subsubsection{Zeolite Supported Catalysts}

Many research groups have used Zeolites as support for iron-based FTO catalysts due to their shape-selectivity and molecular sieve character [101-107]. Zeolites are mainly used as acidic catalysts, and the strength and concentration of the acids sites can be adjusted according to the required properties. Cheon et al. [101] studied the effect of active components content on the catalytic performance of $\mathrm{Fe}-\mathrm{Cu}-\mathrm{K} / \mathrm{ZSM}-5$ catalysts with the fixed weight ratio of Fe:Cu:K of 1:0.1:0.2 and different contents of 5:0.5:1 (5Fe/ZSM-5), 20:2:4 (20Fe/ZSM-5), 30:3:6 (30Fe/ZSM-5) and 40:4:8 (40Fe/ZSM-5). The BET surface area of the catalysts decreased by increasing the metal contents, while at the same time, the pore sizes were increased. Active metals could block the micropores of the zeolites, and a higher content of metals resulted in a greater decrease in the surface area. The surface properties of the catalyst with $40 \%$ of iron loading is almost similar to the active component itself, and XRD results confirmed it, where the peaks belong to the ZSM-5 were very weak for this sample, and the peaks for $\alpha-\mathrm{Fe}_{2} \mathrm{O}_{3}$ were the main observed peaks. The $\alpha-\mathrm{Fe}_{2} \mathrm{O}_{3}$ species were transformed into metallic iron after reduction, which then, during the FT reaction, carburized to iron carbides as the FT active phase. The higher activity is related to the presence of more iron carbide in the spent 40Fe/ZSM-5 catalyst. The facile formation of iron carbides and the better reducibility of iron oxides by increasing the metal content resulted in a higher $\mathrm{CO}$ conversion and $\mathrm{C}_{5+}$ formation. The highest content of weak and total acid sites was observed for the $5 \mathrm{Fe} / \mathrm{ZSM}-5$ catalyst, and they followed the order of 5Fe/ZSM-5 > 20Fe/ZSM-5 > 30Fe/ZSM-5 > 40Fe/ZSM-5. Similar to the results obtained in their previous study [106], the catalyst with the lowest acid sites showed the highest catalytic activity and also the highest olefin formation [101].

The catalytic activity of a series of promoted iron catalysts supported on different types of zeolites including mordenite $\left(\mathrm{Si} / \mathrm{Al}=6\right.$, surface area $\left.=420 \mathrm{~m}^{2} / \mathrm{g}\right)$, beta-zeolite $\left(\mathrm{Si} / \mathrm{Al}=12.5\right.$, surface area $\left.=680 \mathrm{~m}^{2} / \mathrm{g}\right)$, and ZSM-5 $\left(\mathrm{Si} / \mathrm{Al}=25\right.$, surface area $\left.=425 \mathrm{~m}^{2} / \mathrm{g}\right)$ prepared by impregnation method, was studied by Kang et al. [104]. The total metal loading of $20 \mathrm{wt}$ \% with the Fe/Cu/K weight ratio of 20/2/4 was used in this study. The presence of $\mathrm{Cu}$ enhanced the reducibility and decreased the iron reduction temperature and operating temperature. The activity and selectivity during the reaction were also stabilized in the presence of $\mathrm{Cu}$. The total acid sites, including weak and strong acid sites, followed the order of FeCuK/Mordenite $>$ FeCuK/Beta-zeolite $>$ FeCuK/ZSM-5. The catalytic activity of the catalysts was related to their reducibility in this order: FeCuK/ZSM-5 > FeCuK/Mordenite $>\mathrm{FeCuK} /$ Beta-zeolite. The formation of more iron carbides as an active phase at the higher degrees of reducibility in ZSM-5 supported catalyst could enhance the catalytic activity. Different iron phases such as iron metal, iron carbides, or $\mathrm{Fe}_{3} \mathrm{O}_{4}$ were suggested as the active phases in the FT reaction. The ZSM-5 supported catalyst showed the highest selectivity to $\mathrm{C}_{2}-\mathrm{C}_{4}$ olefins, followed by beta-zeolite and mordenite-supported catalysts. The olefin formation could be suppressed due to the stronger acid sites in the mordenite-supported catalyst [106].

Later, Kang et al. [107] investigated the catalytic properties and activities of a series of promoted iron catalysts supported on ZSM-5 with different Si / Al ratios of 25, 40, and 140. Similar to their previous study [106], the total metal loading of $20 \mathrm{wt} \%$ with the $\mathrm{Fe} / \mathrm{Cu} / \mathrm{K}$ ratio of 20/2/4 (by weight) was used in this research. It was observed that the total acid sites decreased by increasing the $\mathrm{Si} / \mathrm{Al}$ ratio of the support (Table S5). At the higher Si content, a decrease in the interaction of iron species and aluminum of zeolite resulted in a better reduction of $\mathrm{Fe}_{3} \mathrm{O}_{4}$ to $\mathrm{Fe}$ metal. The reduction peak of the catalysts gradually 
shifted to higher temperatures by lowering the $\mathrm{Si} / \mathrm{Al}$ ratios, indicating the stronger MSI and difficult reduction of the catalyst with a lower $\mathrm{Si} / \mathrm{Al}$ ratio, which resulted in the formation of smaller metal particles on the surface. The strong interaction of small iron particles with acid sites of zeolite could suppress the sintering of the metal particles, facilitate the formation of iron carbides, and thus, increase the catalytic activity during an FT reaction. The catalyst with the lowest amount of strong acid sites (highest amount of weak acid sites) showed the highest selectivity to light olefins. In this study, unlike the total acid sites and weak acid sites, the number of strong acid sites increased by increasing the Si/Al ratio, suppressing the light olefins formation [107].

The addition of HZSM- 5 to the $\mathrm{FeMnK} / \mathrm{SiO}_{2}$ catalyst significantly affected the catalytic performance during the FTO reaction [108]. The $\mathrm{FeMnK} / \mathrm{SiO}_{2}$ catalyst $(100 \mathrm{Fe} / 10 \mathrm{Mn} / 5 \mathrm{~K} /$ $20 \mathrm{SiO}_{2}$ ) was prepared using the co-precipitation method, and then the FeMnK/SiO $2-\mathrm{HZSM}$ 5 catalysts were prepared by powder-mixing with the FeMnK/SiO $2: H Z S M-5$ mass ratio of $1: 1$. The pore structure of the catalysts did not change following the addition of HZSM-5, while the BET surface area increased. In addition, the HZSM-5 zeolites with the lower $\mathrm{Si} / \mathrm{Al}$ ratios had higher BET surface areas (Table 5), which could be due to the decrease in the crystal sizes of HZSM-5. The crystal sizes of FeMnK/SiO $2-H Z S M-5(\mathrm{Si} / \mathrm{Al}=80)$ were larger than the crystal sizes of $\mathrm{FeMnK} / \mathrm{SiO}_{2}-\mathrm{HZSM}-5(\mathrm{Si} / \mathrm{Al}=27$ ). The addition of HZSM-5 also enhanced the reducibility of the catalyst, the reduction temperatures shifted to lower temperatures, and an increase in the $\mathrm{Si} / \mathrm{Al}$ ratios in the HZSM-5 zeolite resulted in a further decrease in the reduction temperatures. Zeolites with the larger Si/Al ratios had larger crystal sizes which can enhance the reducibility of the catalyst.

Table 5. Textural properties and catalytic performances of catalysts at $300{ }^{\circ} \mathrm{C}, 2 \mathrm{MPa}$, and $\mathrm{H}_{2} / \mathrm{CO}=1[108]$.

\begin{tabular}{|c|c|c|c|c|c|c|}
\hline & $\mathrm{FeMnK}_{/ \mathrm{SiO}_{2}}$ & $\begin{array}{c}\text { HZSM-5 } \\
(\mathrm{Si} / \mathrm{Al}=27)\end{array}$ & $\begin{array}{c}\mathrm{FeMnK} / \mathrm{SiO}_{2-} \\
\mathrm{HZSM} \\
(\mathrm{Si} / \mathrm{Al}=27)\end{array}$ & $\begin{array}{c}\mathrm{FeMnK} / \mathrm{SiO}_{2}- \\
\mathrm{HZSM} \\
(\mathrm{Si} / \mathrm{Al}=38)\end{array}$ & $\begin{array}{c}\mathrm{FeMnK} / \mathrm{SiO}_{2}- \\
\mathrm{HZSM} \\
(\mathrm{Si} / \mathrm{Al}=50)\end{array}$ & $\begin{array}{c}\mathrm{FeMnK}_{\mathrm{SiO}}- \\
\mathrm{HZSM} \\
(\mathrm{Si} / \mathrm{Al}=\mathbf{8 0})\end{array}$ \\
\hline \multicolumn{7}{|l|}{ Textural properties } \\
\hline $\mathrm{S}_{\mathrm{BET}}\left(\mathrm{m}^{2} / \mathrm{g}\right)$ & 165.3 & 296.5 & 258.0 & 249.0 & 217.2 & 226.6 \\
\hline Pore volume $\left(\mathrm{cm}^{3} / \mathrm{g}\right)$ & 0.209 & 0.108 & 0.179 & 0.166 & 0.135 & 0.167 \\
\hline Pore size $(\mathrm{nm})$ & 3.95 & 5.98 & 3.69 & 3.72 & 3.69 & 3.69 \\
\hline \multicolumn{7}{|l|}{ Catalytic performance } \\
\hline CO conversion $(\%)$ & 82.47 & - & 63.84 & 62.71 & 58.93 & 66.31 \\
\hline $\mathrm{CO}_{2}$ selectivity $(\%)$ & 46.75 & - & 40.23 & 41.60 & 40.02 & 43.09 \\
\hline \multicolumn{7}{|c|}{ Hydrocarbon distribution (\%) } \\
\hline $\mathrm{CH}_{4}$ & 17.42 & - & 12.36 & 11.27 & 11.07 & 10.72 \\
\hline $\mathrm{C}_{2}=\mathrm{C}_{4}$ & 19.09 & - & 6.86 & 9.60 & 10.68 & 11.20 \\
\hline $\mathrm{C}_{2}-\mathrm{C}_{4}$ & 10.64 & - & 12.73 & 10.64 & 10.69 & 8.88 \\
\hline $\mathrm{O} / \mathrm{P}\left(\mathrm{C}_{2}-\mathrm{C}_{4}\right)$ & 1.79 & - & 0.54 & 0.90 & 1.00 & 1.26 \\
\hline $\mathrm{C}_{5+}$ & 52.84 & - & 68.05 & 68.48 & 67.57 & 69.19 \\
\hline \multicolumn{7}{|c|}{ Selectivity in $\mathrm{C}_{5+}$ hydrocarbon (\%) } \\
\hline Olefins & 55.19 & - & 42.87 & 46.80 & 45.21 & 42.78 \\
\hline Paraffins & 44.81 & - & 38.31 & 39.52 & 41.68 & 44.14 \\
\hline Aromatics & 0.00 & - & 18.82 & 13.68 & 13.11 & 13.08 \\
\hline
\end{tabular}

The acidic properties of $\mathrm{FeMnK} / \mathrm{SiO}_{2}$ also changed after the addition of HZSM-5, and the amount of weak and strong acid sites increased by decreasing of $\mathrm{Si} / \mathrm{Al}$ ratio. The high $\mathrm{CO}$ conversion of $82.47 \%$ and $\mathrm{C}_{2}-\mathrm{C}_{4}$ olefins selectivity of $19.09 \%$ were obtained over FeMnK $/ \mathrm{SiO}_{2}$ catalyst. The HZSM-5 ( $\left.\mathrm{Si} / \mathrm{Al}=27\right)$, as a catalyst alone, did not have any activity during the FT reaction, but after physically mixing with the $\mathrm{FeMnK} / \mathrm{SiO}_{2}$ catalyst, the $C_{2}-C_{4}$ olefins selectivity decreased significantly from $19.09 \%$ to $6.86 \%$. In contrast, the selectivities to $\mathrm{C}_{5+}$ hydrocarbons and aromatics in this range were increased. The selectivity to $\mathrm{C}_{2}-\mathrm{C}_{4}$ olefins was enhanced by increasing the $\mathrm{Si} / \mathrm{Al}$ ratios, which resulted in the lower acid sites. The conversion of olefins to aromatics enhanced at the lower ratios of $\mathrm{Al} / \mathrm{Si}$ and 
higher amount of strong Brønsted acid sites. However, it is worth noting that due to the cracking of long-chain hydrocarbons in the presence of excessive strong Brønsted acid sites, the selectivity to aromatics could be decreased [108].

The addition of $\mathrm{MnO}$ as a promoter to the Fe catalyst supported on Si-2 zeolite resulted in a better dispersion and reducibility of iron particles and suppressed the secondary reactions of olefin hydrogenation (Table S6) [105]. The olefin production increased when using the Si-2 zeolite as support, and with the addition of Mn as a promoter, the catalyst activity reached a maximum and then decreased slightly, while at the highest $\mathrm{CO}$ conversion (77.6\%), the lowest selectivity to light olefins (39.6\%) and $\mathrm{O} / \mathrm{P}$ ratio $(2.08)$ was observed. Due to the suppression of olefin hydrogenation, the $C_{2}-C_{4}$ olefin production increased by increasing the Mn content [105]. The addition of a proper binder (i.e., $\mathrm{TiO}_{2}$ ) to the Fe$\mathrm{MnO}$ catalyst supported on silicalite-2 (Si-2) zeolite could improve the catalyst mechanical strength and catalyst reactivity without any adverse effect on the selectivity to light olefins due to the improved electron transfer between $\mathrm{Fe}^{2+}$ and/or $\mathrm{Fe}^{3+}$ components and $\mathrm{TiO}_{2}$ (Table S6). The basicity of the support plays an important role in the formation of light olefins in the FTO process over Fe catalysts promoted by MnO. Later, Xu et al. [109] reported that the simultaneous addition of $\mathrm{Mn}$ and $\mathrm{K}$ promoters resulted in a further improvement in the catalytic activity and light olefin production.

It was reported that the addition of zeolite to the AC-supported iron catalysts in a dual-bed reactor (separate-beds) could alter the product distributions by cracking longchain hydrocarbons, isomerization of n-paraffins, oligomerization of olefins, and formation of aromatics $[110,111]$. The $C_{2}-C_{4}$ olefins content in the products decreased by the addition of ZSM-5 due to the higher possibility of oligomerization in the presence of ZSM-5, and the olefin formation decreased by the further increase in the amount of ZSM- 5 . The FT and WGS reaction rates increased by increasing the temperature from $280{ }^{\circ} \mathrm{C}$ to $300{ }^{\circ} \mathrm{C}$, but further temperature increases did not enhance the reaction rates. Formation of aromatics increased sharply in the presence of zeolite, and by increasing the reaction temperature from $280{ }^{\circ} \mathrm{C}$ to $300{ }^{\circ} \mathrm{C}$, total $\mathrm{C}_{2}-\mathrm{C}_{4}$ hydrocarbons and aromatics concentrations from 2.25 to 6.05 (g carbon/day) and 262 to 1762 (mg carbon/day), respectively [110]. A summary of reactions occurring over the catalyst (Fe/ AC and the zeolite) is shown in Figure 10 [111]. Syngas is converted to $\mathrm{C}_{1}-\mathrm{C}_{5}, \mathrm{C}_{6+}$, alcohols, and light olefins under an iron-based catalyst.

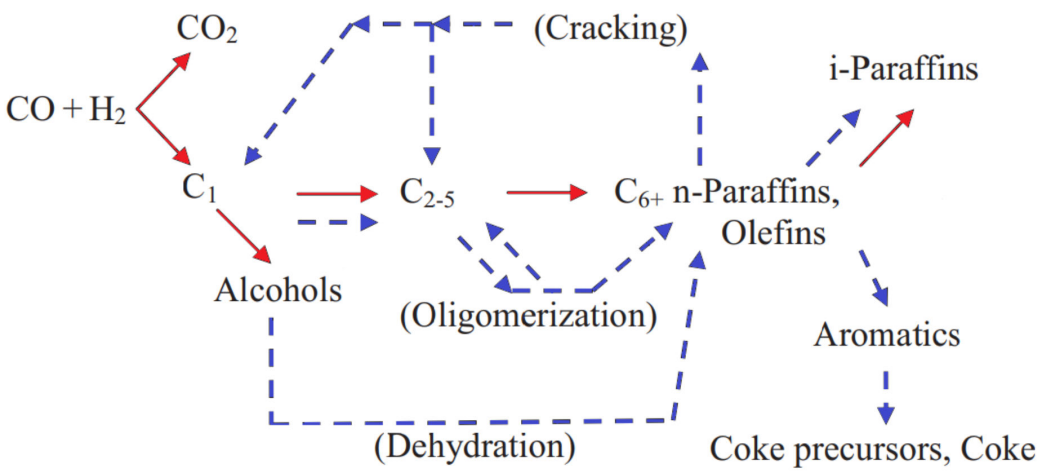

Figure 10. Summary of reactions occurring over Fe catalyst (Fe, unbroken red arrows) and the zeolite (Z, blue dashed arrows) [111].

Oligomerization of $\mathrm{C}_{2}-\mathrm{C}_{5}$ products result in the formation of heavier n-paraffins, which can be cracked and isomerized to lower-chain hydrocarbons and i-paraffins over the zeolite catalyst. The $\mathrm{C}_{6+} \mathrm{n}$-paraffins also go through the aromatization reaction to produce aromatic compounds such as benzene, toluene, and p-xylene. Undesired coke is also produced on the surface of zeolite using aromatic molecules as precursors. Dehydration of alcohols to hydrocarbons can also occur over the zeolite catalysts, where water is produced 
as a by-product in this process. Acid catalysts could enhance the formation of isomers and aromatic in the range of $\mathrm{C}_{5}-\mathrm{C}_{20+}$ at the expense of product olefins.

The catalytic activity of the FeZnNa/Zeolites catalysts for the production of light olefins in a dual-bed catalyst was studied by Hou et al. [112]. Different types of zeolites including $\mathrm{HY}, \mathrm{NaY}$, ZSM-5, SAPO-34, $\mathrm{H} \beta, \mathrm{Li} \beta, \mathrm{Na} \beta, \mathrm{K} \beta$, and $\mathrm{Rb} \beta$ were used in this study. The effect of zeolites in the catalytic reaction of $\mathrm{CO}$ hydrogenation was evaluated in a dual-bed catalyst, whereas the zeolite powder layer was placed below the FeZnNa layer, and the layers were separated completely by silica wool. The acidity of the zeolites, which plays an important role in the hydrocracking of long-chain hydrocarbons, were measured and the acidities $\left(\mathrm{NH}_{3}\right.$ desorption $\left.(\mathrm{mmol} / \mathrm{g})\right)$ were in the following order: HY (3.5) $>\mathrm{ZSM}-5$ (2.3) $>$ SAPO-34 (2.2) > H $\beta(2.0)>\mathrm{NaY}(1.6)>\mathrm{Li} \beta(1.2)>\mathrm{Na} \beta(1.0)>\mathrm{K} \beta(0.5)>\mathrm{Rb} \beta(0.4)$. The zeolites including HY, ZSM-5, SAPO-34, and $\mathrm{H} \beta$ showed two $\mathrm{NH}_{3}$ desorption peaks at about $200{ }^{\circ} \mathrm{C}$ and $340-450{ }^{\circ} \mathrm{C}$, which were attributed to the weak and strong acid sites, respectively, while $\mathrm{Na} \beta$ and $\mathrm{NaY}$ had only one peak belong to the weak acid site. The number of acid sites in the zeolite $\beta$ also was affected by the basicity of exchanged alkali metals $(\mathrm{Na}, \mathrm{K}, \mathrm{Li}$, and $\mathrm{Rb})$, and by increasing the atomic numbers of the exchanged alkalis, the number of acid sites was decreased. The FeZnNa catalyst showed the $\mathrm{C}_{2}-\mathrm{C}_{4}$ olefins selectivity, of $26.4 \%$, at a CO conversion of $87.6 \%$ (Table S7). The addition of zeolites resulted in a slight increase in the $\mathrm{CO}$ conversion, while the product distribution was significantly affected. In general, the olefin production increased following the addition of zeolites. A series of reactions, including olefin readsorption, hydrocracking, and isomerization of the primary hydrocarbons, occur on the zeolite layer. The highest $C_{2}-C_{4}$ olefins selectivity of $50.5 \%$ was obtained over the $\mathrm{FeZnNa} / \mathrm{Na}$.

Bae et al. [113] studied the catalytic properties and performance of 20Fe-Cu-4K/ZSM-5 catalysts (20 wt.\% Fe and $4 \mathrm{wt} . \% \mathrm{~K}$ ) with different $\mathrm{Cu}$ contents of 0, 2, 4, and $6 \mathrm{wt.} \%$. Catalysts were prepared by impregnating metal precursors on ZSM-5 ( $\mathrm{Si} / \mathrm{Al}-25$, surface area $=425 \mathrm{~m}^{2} / \mathrm{g}$ ), and their catalytic activities were evaluated in a fixed-bed reactor at $300{ }^{\circ} \mathrm{C}, 1 \mathrm{MPa}$, and $\mathrm{H}_{2} / \mathrm{CO}$ ratio of 2 . The catalytic activities were in this order: $\mathrm{Fe}-\mathrm{Cu}(2)-\mathrm{K} / \mathrm{ZSM} 5>\mathrm{Fe}-\mathrm{Cu}(0)-\mathrm{K} / \mathrm{ZSM} 5>\mathrm{Fe}-\mathrm{Cu}(4)-\mathrm{K} / \mathrm{ZSM} 5>\mathrm{Fe}-\mathrm{Cu}(6)-\mathrm{K} / \mathrm{ZSM} 5$, which is similar to the trend of weak acid sites of the catalysts (Table S8). As mentioned earlier by Kang et al. [107], the olefin formation is suppressed in the presence of strong acid sites, while it is enhanced in the presence of more weak acid sites.

A series of zeolite (hollow silicalite-1 zeolite)-encapsulated FeMnK catalysts with enhanced selectivity to light olefins, via FT reaction, were developed by Zhu et al. [114]. The results confirmed that the selectivity of light olefins reached 50.6\% over FeMnK@H-S-1 catalyst. It was found that the higher hierarchy factor, which is the result of the relative pore volume of micropores multiplied by the relative specific surface area of mesopores, was an important parameter to obtain a higher light olefin selectivity. Besides, the modest $\mathrm{H}_{2}$ activation capacity and lower desorption energy of olefins could be further reasons for the higher olefin selectivity. The olefin secondary reactions through readsorption were significantly reduced over this FeMnK@H-S-1 catalyst.

Recently, Yahyazadeh et al. [115] did a comprehensive review on catalyst development for light olefins production via FTS, and the effects of metals, supports, and promoters on the catalyst performance were discussed. They have studied the Co and Fe as the main active metals in FT reaction, and the effect of crystal phase, crystal size, and pore size of these catalysts have been investigated in that work. They reported that the iron carbide is the most crucial active phase for olefin production through FT reaction, and also the larger pore size of iron-based catalysts could result in a higher olefin production and decrease the readsorption and secondary reactions. According to the findings reported in the literature, Yahyazadeh et al. [115] and Ma and Dalai [116] also reported that the support's properties could significantly affect the catalyst performance. The desirable interaction with metal and support needs to be considered during the selection of the support. As mentioned earlier in the current review paper, the lifetime of catalyst, metal dispersion, and reducibility of active metal are strongly affected by the strength of MSI. 
Basicity of the catalysts, which is influenced by the type of support, can also be improved by the addition of promoters such as alkali metals. The dissociative adsorption of $\mathrm{CO}$ and selectivity to olefins could be enhanced in the presence of strong basic sites. The addition of alkali metals can change the catalyst reducibility and phase transition. It can also enhance the catalyst reducibility at higher temperatures while decreasing the reducibility of catalysts at lower temperatures. The deactivation of Fe and Co catalysts was also investigated, and different deactivation mechanisms, including carbidation, active phase oxidation, surface carbon formation, surface reconstruction, sintering, attrition, and poisoning, were discussed by Yahyazadeh et al. [115].

\section{Concluding Remarks}

Light olefins are the key components in chemical industries, and they are used to produce several derivatives used in our daily life. The various technologies for light-olefins production are divided into two main categories of direct and indirect processes. In the direct process, syngas is directly converted into light olefins, while, in the indirect process, syngas is first converted into an intermediate, then transformed into light olefins. In the Fischer-Tropsch to olefin (FTO) process, light olefins will be produced directly through a catalytic reaction over catalysts such as iron and cobalt. This process aims to increase the production of light olefins with the lowest methane formation and also avoid the production of excess $\mathrm{CO}_{2}$. Iron-based catalysts with lower price than cobalt, higher selectivity to olefins, lower selectivity to methane, and higher resistance against contaminants are promising candidates for olefins production via FT reaction.

The fresh iron catalyst $\left(\alpha-\mathrm{Fe}_{2} \mathrm{O}_{3}\right)$ was reduced to $\mathrm{Fe}_{3} \mathrm{O}_{4}, \mathrm{FeO}$, and $\mathrm{Fe}^{0}$, and then after exposing to syngas during the FT reaction, the reduced species were transformed into iron carbides $\left(\varepsilon-\mathrm{Fe}_{2} \mathrm{C}, \varepsilon^{\prime}-\mathrm{Fe}_{2.2} \mathrm{C}, \chi-\mathrm{Fe}_{5} \mathrm{C}_{2}, \mathrm{Fe}_{7} \mathrm{C}_{3}\right.$, and $\left.\theta-\mathrm{Fe}_{3} \mathrm{C}\right)$ which act as active phases in FT reaction. Transition metals such as $\mathrm{Ti}, \mathrm{Mn}$, and $\mathrm{V}$, with a high affinity to carbon monoxide, were reported to be excellent promoters for olefin production. The promotion of iron catalysts with alkali metals has been widely investigated. By the addition of alkali promoters, the $\mathrm{CO}$ dissociative adsorption and surface coverage of dissociated $\mathrm{CO}$ could be increased and inhibit the olefin readsorption; thus, the selectivity to olefins could be enhanced. The selectivity to olefins could also be improved by the combination of iron and other transition metal oxides. Manganese has been used extensively for this purpose, and both the activity and chain propagation become increased by the incorporation of manganese oxide. The selectivity to light olefins could be enhanced due to the presence of a sufficient amount of active sites for the adsorption and decomposition of $\mathrm{CO}$ molecules on the catalyst's surface. Thus, the enhanced carburization environment on the surface and inhibited hydrogenation rate could lead to a higher selectivity to light olefins.

Despite their ability to produce light olefins via FT reaction, bulk and unsupported iron catalysts suffer from low stability, physical degradation at high reaction temperatures, and the formation of fine particles which can plug the fixed-bed reactor and cause a large pressure drop, or making difficulties in the separation of these fine catalysts in slurry reactors. In addition, in the presence of bulk iron catalysts, a Boudouard reaction $\left(2 \mathrm{CO} \leftrightarrow \mathrm{CO}_{2}+\mathrm{C}\right)$ may occur, and formed carbon can block the active sites and destroy the particles in bulk iron catalyst; consequently, the FT reaction becomes inhibited and the activity decreases. The stability and lifetime of the catalyst could be enhanced using a proper supporting material. According to their acidic and basic properties, ability to stabilize metal dispersion, and geometric properties, supports can alter the catalyst activity and the product distribution. The catalyst's lifetime, reducibility of active metals, and metal dispersion are significantly affected by the strength of metal-support interaction (MSI). The catalytic performances of iron-based catalysts supported on silica, alumina, and zeolites as the most common supporting materials for olefin production via the FTO process have been discussed in this paper. Alumina and silica supports were widely used to improve the mechanical and structural stability of iron-based catalysts. The higher dispersion of smaller metal particles with a lower degree of carbidization could be observed in the support with 
a smaller pore size and stronger MSI, while carbidization of the larger iron particles located on the support with the larger pore size is much easier. Zeolites are also used as a support for iron-based catalysts. The strength and amount of acid sites could be adjusted by altering the $\mathrm{Si} / \mathrm{Al}$ ratio in these supports. The larger $\mathrm{Si} / \mathrm{Al}$ ratios could result in the formation of larger crystal size, lower MSI, and better reducibility properties, consequently enhancing the catalytic activity. In addition, the acidity, mainly the strong acid site, could be increased by lowering the $\mathrm{Si} / \mathrm{Al}$ ratio, which can suppress the olefin formation. Therefore, olefin production could be optimized by adjusting the acidity and porosity of the zeolites.

Iron-based catalysts, which are inexpensive, have a higher tolerance to sulfur, and high selectivity to light olefins can be used as an efficient catalyst for light olefin production via FT reaction. According to the discussions explored in this paper, the activity and selectivity of the iron-based catalysts could be affected by different parameters, including the support and promoter. The addition of a proper promoter, such as alkali metals, can enhance olefin production. An appropriate support for the iron-based catalyst for FTO reaction needs to provide a good distribution of active metals on the surface, enhance the degree of reducibility and formation of the active phase, and increase the possibility of the contact of reactants and active sites. The catalyst also needs to have high stability and lifetime to ensure its long-term activity without altering the product selectivity. The selection of suitable catalysts and the optimized reaction conditions can increase the feasibility of the FTO process for the production of light olefins.

Supplementary Materials: The following supporting information can be downloaded at: https: / / www.mdpi.com/article/10.3390/catal12020174/s1. Figure S1: Structural models for $\varepsilon$-carbide, Hägg carbide, and magnetite, Figure S2: Effect of Fe/Co molar ratios on the catalytic performance of the Fe/Co catalysts in FTO reaction $\left(\mathrm{H}_{2} / \mathrm{CO}=1 / 4,450{ }^{\circ} \mathrm{C}\right)$, Figure S3: CO conversions for the reduced catalysts at different reaction temperatures, Table S1: Activity/selectivity of the perovskite-like oxides in FTO reaction, Table S2: Catalytic performance of Mn promoted Fe catalysts in Fischer-Tropsch synthesis, Table S3: Different phases of iron in the fresh, reduced and spent catalysts, Table S4: Crystalline phases of the prepared catalysts, Table S5: The properties and catalytic activity of Fe-CuK/ZSM-5 catalysts, Table S6: The catalytic performance of Fe-MnO catalyst supported on Si- 2 zeolite, Table S7: The catalytic performance of dual-bed FeZnNa/Zeolite catalysts after $24 \mathrm{~h}$ at $330{ }^{\circ} \mathrm{C}, 2.0$ $\mathrm{MPa}$, and $\mathrm{H}_{2} / \mathrm{CO}=1$, Table S8: Surface acidity and catalytic activity of Fe-Cu-K/ZSM-5 catalysts.

Funding: This publication is a result of the project CACTU, Reg. No. CZ.02.1.01/0.0/0.0/17_049/ 0008397, which has been co-financed by European Union from the European Regional Development Fund through the Operational Programme Research, Development and Education. The result was achieved using the infrastructure of the project Efficient Use of Energy Resources Using Catalytic Processes (LM2018119) which has been financially supported by MEYS within the targeted support of large infrastructures.

Conflicts of Interest: The authors declare that they have no known competing financial interests or personal relationships that could have appeared to influence the work reported in this paper.

\section{References}

1. Dry, M.E. The Fischer-Tropsch process: 1950-2000. Catal. Today 2002, 71, 227-241. [CrossRef]

2. Deloitte. The Future of Petrochemicals: Growth Surrounded by Uncertainty. 2019. Available online: https://www2.deloitte.com/ content/dam/Deloitte/us/Documents/energy-resources/us-the-future-of-petrochemicals.pdf (accessed on 28 June 2021).

3. Blay, V.; Louis, B.; Miravalles, R.; Yokoi, T.; Peccatiello, K.A.; Clough, M.; Yilmaz, B. Engineering zeolites for catalytic cracking to light olefins. ACS Catal. 2017, 7, 6542-6566. [CrossRef]

4. An, Y.; Lin, T.; Yu, F.; Yang, Y.; Zhong, L.; Wu, M.; Sun, Y. Advances in direct production of value-added chemicals via syngas conversion. Sci. China Chem. 2017, 60, 887-903. [CrossRef]

5. Torres Galvis, H.M.; de Jong, K.P. Catalysts for production of lower olefins from synthesis gas: A review. ACS Catal. 2013, 3, 2130-2149. [CrossRef]

6. Janardanarao, M. Direct catalytic conversion of synthesis gas to lower olefins. Ind. Eng. Chem. Res. 1990, 29, 1735-1753. [CrossRef]

7. Wang, S.; Wang, P.; Shi, D.; He, S.; Zhang, L.; Yan, W.; Qin, Z.; Li, J.; Dong, M.; Wang, J.; et al. Direct conversion of syngas into light olefins with low $\mathrm{CO}_{2}$ emission. ACS Catal. 2020, 10, 2046-2059. [CrossRef] 
8. Jiao, F.; Li, J.; Pan, X.; Xiao, J.; Li, H.; Ma, H.; Wei, M.; Pan, Y.; Zhou, Z.; Li, M.; et al. Selective conversion of syngas to light olefins. Science 2016, 351, 1065-1068. [CrossRef]

9. Gholami, Z.; Tišler, Z.; Rubáš, V. Recent advances in Fischer-Tropsch synthesis using cobalt-based catalysts: A review on supports, promoters, and reactors. Catal. Rev. 2020, 63, 512-595. [CrossRef]

10. Gholami, Z.; Zabidi, N.A.M.; Gholami, F.; Ayodele, O.B.; Vakili, M. The influence of catalyst factors for sustainable production of hydrocarbons via Fischer-Tropsch synthesis. Rev. Chem. Eng. 2017, 33, 337-358. [CrossRef]

11. Zhang, Q.; Cheng, K.; Kang, J.; Deng, W.; Wang, Y. Fischer-Tropsch catalysts for the production of hydrocarbon fuels with high selectivity. ChemSusChem 2014, 7, 1251-1264. [CrossRef]

12. Van de Loosdrecht, J.; Niemantsverdriet, J. 5.4 synthesis gas to hydrogen, methanol, and synthetic fuels. In Chemical Energy Storage; Schlögl, R., Ed.; De Gruyter: Berlin, Germany, 2012; pp. 443-458. [CrossRef]

13. Agrimi, G.; Alexopoulou, E.; Bartzoka, E.D.; Buonerba, A.; Cavani, F.; Christou, M.; Colucci, A.; Couturier, J.L.; Crestini, C.; Dubois, J.L.; et al. Biorefineries: An Introduction; De Gruyter: Berlin, Germany, 2015. [CrossRef]

14. Jahangiri, H.; Bennett, J.; Mahjoubi, P.; Wilson, K.; Gu, S. A review of advanced catalyst development for Fischer-Tropsch synthesis of hydrocarbons from biomass derived syn-gas. Catal. Sci. Technol. 2014, 4, 2210-2229. [CrossRef]

15. Van Der Laan, G.P.; Beenackers, A.A.C.M. Kinetics and selectivity of the Fischer-Tropsch synthesis: A literature review. Catal. Rev. 1999, 41, 255-318. [CrossRef]

16. Rofer-DePoorter, C.K. A comprehensive mechanism for the Fischer-Tropsch synthesis. Chem. Rev. 1981, 81, 447-474. [CrossRef]

17. China, S. Synfuels China. 2019. Available online: http://www.synfuelschina.com.cn/en/about/ (accessed on 10 December 2021).

18. Minchener, A.J. Coal-to-Oil, Gas and Chemicals in China; Report CCC/181; United States Energy Association: Washington, DC, USA, 2011; Available online: https://usea.org/sites/default/files/022011_Coal-to-oil,\%20gas\%20and\%20chemicals\%20in\%20 China_ccc181.pdf (accessed on 21 September 2021).

19. Moulijn, J.A.; Makkee, M.; van Diepen, A.E. Chemical Process Technology, 2nd ed.; John Wiley \& Sons: Hoboken, NJ, USA, 2013.

20. Rauch, R.; Kiennemann, A.; Sauciuc, A. Fischer-Tropsch Synthesis to Biofuels (BtL process). In The Role of Catalysis for the Sustainable Production of Bio-Fuels and Bio-Chemicals; Elsevier: Amsterdam, The Netherlands, 2013; pp. $397-443$.

21. Van de Loosdrecht, J.; Botes, F.G.; Ciobica, I.M.; Ferreira, A.C.; Gibson, P.; Moodley, D.J.; Saib, A.M.; Visagie, J.L.; Weststrate, C.J.; Niemantsverdriet, J.W. Fischer-Tropsch synthesis: Catalysts and chemistry. In Comprehensive Inorganic Chemistry II, 2nd ed.; Reedijk, J., Poeppelmeier, K., Eds.; Elsevier: Amsterdam, The Netherlands, 2013; pp. 525-557. [CrossRef]

22. Maitlis, P.M.; de Klerk, A. Greener Fischer-Tropsch Processes: For Fuels and Feedstocks; John Wiley \& Sons: Hoboken, NJ, USA, 2013. [CrossRef]

23. Subramanian, N.; Adeyinka, A.; Spivey, J. Catalytic conversion of syngas to i-butanol - Synthesis routes and catalyst developments: A review. Catalysis 2015, 26, 161-178. [CrossRef]

24. Dry, M.E.; Steynberg, A.P. Chapter 5-Commercial FT process applications. Stud. Surf. Sci. Catal. 2004, 152, 406-481. [CrossRef]

25. Spath, P.L.; Dayton, D.C. Preliminary Screening-Technical and Economic Assessment of Synthesis GAS to fuels and Chemicals with Emphasis on The Potential for Biomass-Derived Syngas; National Renewable Energy Lab.: Golden, CO, USA, 2003.

26. Basu, P. Chapter 12-Production of synthetic fuels and chemicals from biomass. In Biomass Gasification, Pyrolysis and Torrefaction, 3rd ed.; Basu P, Ed.; Academic Press: Cambridge, MA, USA, 2018; pp. 415-443. [CrossRef]

27. Keim, W. Catalysis in C1 Chemistry; Springer: Berlin/Heidelberg, Germany, 2012.

28. Dry, M.E. Fischer-Tropsch synthesis over iron catalysts. Catal. Lett. 1990, 7, 241-251. [CrossRef]

29. Masudi, A.; Jusoh, N.W.C.; Muraza, O. Opportunities for less-explored zeolitic materials in the syngas-to-olefins pathway over nanoarchitectured catalysts: A mini review. Catal. Sci. Technol. 2020, 10, 1582-1596. [CrossRef]

30. Torres Galvis, H.M.; Bitter, J.H.; Khare, C.B.; Ruitenbeek, M.; Dugulan, A.I.; de Jong, K.P. Supported iron nanoparticles as catalysts for sustainable production of lower olefins. Science 2012, 335, 835-838. [CrossRef] [PubMed]

31. Abelló, S.; Montané, D. Exploring iron-based multifunctional catalysts for Fischer-Tropsch synthesis: A review. ChemSusChem 2011, 4, 1538-1556. [CrossRef] [PubMed]

32. Sun, J.; Yang, G.; Peng, X.; Kang, J.; Wu, J.; Liu, G.; Tsubaki, N. Beyond cars: Fischer-Tropsch synthesis for non-automotive applications. Chem CatChem 2019, 11, 1412-1424. [CrossRef]

33. Weber, J.L.; Dugulan, I.; de Jongh, P.E.; de Jong, K.P. Bifunctional catalysis for the conversion of synthesis gas to olefins and aromatics. ChemCatChem 2018, 10, 1107-1112. [CrossRef]

34. Karre, A.V.; Dadyburjor, D.B. Review of iron-based catalysts with and without zeolite supports used in fischer-tropsch processes. Chem. Eng. Commun. 2021; in press. [CrossRef]

35. Davis, B.H. Fischer-Tropsch Synthesis: Comparison of performances of iron and cobalt catalysts. Ind. Eng. Chem. Res. 2007, 46, 8938-8945. [CrossRef]

36. Khodakov, A.Y.; Chu, W.; Fongarland, P. Advances in the development of novel cobalt Fischer-Tropsch catalysts for synthesis of long-chain hydrocarbons and clean fuels. Chem. Rev. 2007, 107, 1692-1744. [CrossRef] [PubMed]

37. Ding, M.; Yang, Y.; Wu, B.; Li, Y.; Wang, T.; Ma, L. Study on reduction and carburization behaviors of iron phases for iron-based Fischer-Tropsch synthesis catalyst. Appl. Energy 2015, 160, 982-989. [CrossRef]

38. Ribeiro, M.C.; Jacobs, G.; Davis, B.H.; Cronauer, D.C.; Kropf, A.J.; Marshall, C.L. Fischer-Tropsch synthesis: An in-situ TPREXAFS/XANES investigation of the influence of group I alkali promoters on the local atomic and electronic structure of carburized iron/silica catalysts. J. Phys. Chem. C. 2010, 114, 7895-7903. [CrossRef] 
39. Bian, G.; Oonuki, A.; Koizumi, N.; Nomoto, H.; Yamada, M. Studies with a precipitated iron Fischer-Tropsch catalyst reduced by $\mathrm{H}_{2}$ or CO. J. Mol. Catal. A Chem. 2002, 186, 203-213. [CrossRef]

40. Boudart, M.; McDonald, M.A. Structure sensitivity of hydrocarbon synthesis from carbon monoxide and hydrogen. J. Phys. Chem. 1984, 88, 2185-2195. [CrossRef]

41. Wang, D.; Chen, B.; Duan, X.; Chen, D.; Zhou, X. Iron-based Fischer-Tropsch synthesis of lower olefins: The nature of $\chi^{-F e}{ }_{5} C_{2}$ catalyst and why and how to introduce promoters. J. Energy Chem. 2016, 25, 911-916. [CrossRef]

42. Chen, B.; Wang, D.; Duan, X.; Liu, W.; Li, Y.; Qian, G.; Yuan, W.; Holmen, A.; Zhou, X.; Chen, D. Charge-tuned CO activation over a $\mathrm{X}-\mathrm{Fe}_{5} \mathrm{C}_{2}$ Fischer-Tropsch catalyst. ACS Catal. 2018, 8, 2709-2714. [CrossRef]

43. Sun, J.; Chen, Y.; Chen, J. Towards stable Fe-based catalysts with suitable active phase for Fischer-Tropsch synthesis to lower olefins. Catal. Commun. 2017, 91, 34-37. [CrossRef]

44. Röper, M. Fischer-Tropsch Synthesis. In Catalysis in C1 chemistry; Keim, W., Ed.; Springer: Dordrecht, The Netherlands, 1983; pp. 41-88. [CrossRef]

45. Arakawa, H.; Bell, A.T. Effects of potassium promotion on the activity and selectivity of iron Fischer-Tropsch catalysts. Ind. Eng. Chem. Process. Des. Dev. 1983, 22, 97-103. [CrossRef]

46. Galvis, H.M.T.; Koeken, A.C.; Bitter, J.H.; Davidian, T.; Ruitenbeek, M.; Dugulan, A.I.; de Jong, K.P. Effects of sodium and sulfur on catalytic performance of supported iron catalysts for the Fischer-Tropsch synthesis of lower olefins. J. Catal. 2013, 303, 22-30. [CrossRef]

47. Li, S.; Krishnamoorthy, S.; Li, A.; Meitzner, G.D.; Iglesia, E. Promoted iron-based catalysts for the Fischer-Tropsch synthesis: Design, synthesis, site densities, and catalytic properties. J. Catal. 2002, 206, 202-217. [CrossRef]

48. An, X.; Wu, B.S.; Wan, H.J.; Li, T.Z.; Tao, Z.C.; Xiang, H.W.; Li, Y.W. Comparative study of iron-based Fischer-Tropsch synthesis catalyst promoted with potassium or sodium. Catal. Commun. 2007, 8, 1957-1962. [CrossRef]

49. Cheng, Y.; Lin, J.; Wu, T.; Wang, H.; Xie, S.; Pei, Y.; Yan, S.; Qiao, M.; Zong, B. Mg and K dual-decorated Fe-on-reduced graphene oxide for selective catalyzing $\mathrm{CO}$ hydrogenation to light olefins with mitigated $\mathrm{CO}_{2}$ emission and enhanced activity. Appl. Catal. B Environ. 2017, 204, 475-485. [CrossRef]

50. Li, T.; Wang, H.; Yang, Y.; Xiang, H.; Li, Y. Effect of manganese on the catalytic performance of an iron-manganese bimetallic catalyst for light olefin synthesis. J. Energy Chem. 2013, 22, 624-632. [CrossRef]

51. Özkara-Aydınoğlu, Ş.; Ataç, Ö.; Gül, Ö.F.; Kınayyiğit, Ş.; Şal, S.; Baranak, M.; Boz, İ. $\alpha$-olefin selectivity of Fe-Cu-K catalysts in Fischer-Tropsch synthesis: Effects of catalyst composition and process conditions. Chem. Eng. J. 2012, 181-182, 581-589. [CrossRef]

52. Feyzi, M.; Hassankhani, A. $\mathrm{TiO}_{2}$ supported cobalt-manganese nano catalysts for light olefins production from syngas. J. Energy Chem. 2013, 22, 645-652. [CrossRef]

53. Saglam, M. Effects of vanadium and zinc promotion on the olefin selectivity of iron Fischer-Tropsch catalysts. Ind. Eng. Chem. Res. 1989, 28, 150-154. [CrossRef]

54. Luo, M.; Davis, B.H. Fischer-Tropsch synthesis: Group II alkali-earth metal promoted catalysts. Appl. Catal. A. Gen. 2003, 246, 171-181. [CrossRef]

55. Goldwasser, M.R.; Dorantes, V.E.; Pérez-Zurita, M.J.; Sojo, P.R.; Cubeiro, M.L.; Pietri, E.; González-Jiménez, F.; Lee, Y.N.; Moronta, D. Modified iron perovskites as catalysts precursors for the conversion of syngas to low molecular weight alkenes. J. Mol. Catal. A Chem. 2003, 193, 227-236. [CrossRef]

56. Tian, Z.; Wang, C.; Yue, J.; Zhang, X.; Ma, L. Effect of a potassium promoter on the Fischer-Tropsch synthesis of light olefins over iron carbide catalysts encapsulated in graphene-like carbon. Catal. Sci. Technol. 2019, 9, 2728-2741. [CrossRef]

57. Ma, Z.; Ma, H.; Zhang, H.; Wu, X.; Qian, W.; Sun, Q.; Ying, W. Direct conversion of syngas to light olefins through Fischer-Tropsch synthesis over Fe-Zr catalysts modified with sodium. ACS Omega 2021, 6, 4968-4976. [CrossRef] [PubMed]

58. Van Dijk, W.L.; Niemantsverdriet, J.W.; van dar Kraan, A.M.; van der Baan, H.S. Effects of manganese oxide and sulphate on the olefin selectivity of iron catalysts in the fischer tropsch reaction. Appl. Catal. 1982, 2, 273-288. [CrossRef]

59. Barrault, J.; Renard, C. Selective hydrocondensation of carbon monoxide into light olefins with iron-manganese catalysts. Appl. Catal. 1985, 14, 133-143. [CrossRef]

60. Malessa, R.; Baerns, M. Iron/manganese oxide catalysts for Fischer-Tropsch synthesis. 4. Activity and selectivity. Ind. Eng. Chem. Res. 1988, 27, 279-283. [CrossRef]

61. Jensen, K.B.; Massoth, F.E. Studies on iron-manganese oxide carbon monoxide catalysts: I. Structure of reduced catalyst. J. Catal. 1985, 92, 98-108. [CrossRef]

62. Jensen, K.B.; Massoth, F.E. Studies on iron-manganese oxide carbon monoxide catalysts: II. Carburization and catalytic activity. J. Catal. 1985, 92, 109-118. [CrossRef]

63. Das, C.K.; Das, N.S.; Choudhury, D.P.; Ravichandran, G.; Chakrabarty, D.K. Hydrogenation of carbon monoxide on unsupported Fe-Mn-K catalysts for the synthesis of lower alkenes: Promoter effect of manganese. Appl. Catal. A Gen. 1994, 111, 119-132. [CrossRef]

64. Shen, Y.; Huang, K. Chemisorptive characterization of $\mathrm{Mn}^{2+}$ cation effects on fused iron-catalysts. React. Kinet. Catal. Lett. 1992, 46, 115-121. [CrossRef]

65. Venter, J.; Kaminsky, M.; Geoffroy, G.L.; Vannice, M.A. Carbon-supported Fe Mn and K Fe Mn clusters for the synthesis of $\mathrm{C}_{2} \mathrm{C}_{4}$ olefins from $\mathrm{CO}$ and $\mathrm{H}_{2}$ : I. Chemisorption and catalytic behavior. J. Catal. 1987, 103, 450-465. [CrossRef] 
66. Li, X.; Zhong, B.; Peng, S.; Wang, Q. Fischer-Tropsch synthesis on Fe-Mn ultrafine catalysts. Catal. Lett. 1994, 23, 245-250. [CrossRef]

67. Wang, C.; Wang, Q.; Sun, X.; Xu, L. CO Hydrogenation to light alkenes over Mn/Fe catalysts prepared by coprecipitation and sol-gel methods. Catal. Lett. 2005, 105, 93-101. [CrossRef]

68. Liu, Y.; Teng, B.T.; Guo, X.H.; Li, Y.; Chang, J.; Tian, L.; Hao, X.; Wang, Y.; Xiang, H.W.; Xu, Y.Y.; et al. Effect of reaction conditions on the catalytic performance of Fe-Mn catalyst for Fischer-Tropsch synthesis. J. Mol. Catal. A Chem. 2007, 272, 182-190. [CrossRef]

69. Liu, Y.; Chen, J.-F.; Bao, J.; Zhang, Y. Manganese-modified $\mathrm{Fe}_{3} \mathrm{O}_{4}$ microsphere catalyst with effective active phase of forming light olefins from syngas. ACS Catal. 2015, 5, 3905-3909. [CrossRef]

70. Mirzaei, A.A.; Vahid, S.; Feyzi, M. Fischer-Tropsch synthesis over iron manganese catalysts: Effect of preparation and operating conditions on catalyst performance. Adv. Phys. Chem. 2009, 2009, 151489. [CrossRef]

71. Mirzaei, A.A.; Habibpour, R.; Kashi, E. Preparation and optimization of mixed iron cobalt oxide catalysts for conversion of synthesis gas to light olefins. Appl. Catal. A Gen. 2005, 296, 222-231. [CrossRef]

72. Mirzaei, A.A.; Habibpour, R.; Faizi, M.; Kashi, E. Characterization of iron-cobalt oxide catalysts: Effect of different supports and promoters upon the structure and morphology of precursors and catalysts. Appl. Catal. A Gen. 2006, 301, 272-283. [CrossRef]

73. O'Brien, R.J.; Xu, L.; Bao, S.; Raje, A.; Davis, B.H. Activity, selectivity and attrition characteristics of supported iron Fischer-Tropsch catalysts. Appl. Catal. A Gen. 2000, 196, 173-178. [CrossRef]

74. Shroff, M.D.; Kalakkad, D.S.; Coulter, K.E.; Kohler, S.D.; Harrington, M.S.; Jackson, N.B.; Sault, A.G.; Datye, A.K. Activation of precipitated iron Fischer-Tropsch synthesis catalysts. J. Catal. 1995, 156, 185-207. [CrossRef]

75. Cheng, K.; Virginie, M.; Ordomsky, V.V.; Cordier, C.; Chernavskii, P.A.; Ivantsov, M.I.; Paul, S.; Wang, Y.; Khodakov, A.Y. Pore size effects in high-temperature Fischer-Tropsch synthesis over supported iron catalysts. J. Catal. 2015, 328, 139-150. [CrossRef]

76. Liu, G.; Chen, Q.; Oyunkhand, E.; Ding, S.; Yamane, N.; Yang, G.; Yoneyama, Y.; Tsubaki, N. Nitrogen-rich mesoporous carbon supported iron catalyst with superior activity for Fischer-Tropsch synthesis. Carbon 2018, 130, 304-314. [CrossRef]

77. Alayat, A.; McLlroy, D.N.; McDonald, A.G. Effect of synthesis and activation methods on the catalytic properties of silica nanospring (NS)-supported iron catalyst for Fischer-Tropsch synthesis. Fuel. Process. Technol. 2018, 169, 132-141. [CrossRef]

78. Park, J.-Y.; Lee, Y.-J.; Khanna, P.K.; Jun, K.-W.; Bae, J.W.; Kim, Y.H. Alumina-supported iron oxide nanoparticles as Fischer-Tropsch catalysts: Effect of particle size of iron oxide. J. Mol. Catal. A Chem. 2010, 323, 84-90. [CrossRef]

79. Xu, J.D.; Chang, Z.Y.; Zhu, K.T.; Weng, X.F.; Weng, W.Z.; Zheng, Y.P.; Huang, C.J.; Wan, H.L. Effect of sulfur on $\alpha$-Al ${ }_{2} \mathrm{O}_{3}$-supported iron catalyst for Fischer-Tropsch synthesis. Appl. Catal. A Gen. 2016, 514, 103-113. [CrossRef]

80. Abrokwah, R.Y.; Rahman, M.M.; Deshmane, V.G.; Kuila, D. Effect of titania support on Fischer-Tropsch synthesis using cobalt, iron, and ruthenium catalysts in silicon-microchannel microreactor. Mol. Catal. 2019, 478, 110566. [CrossRef]

81. Duan, X.; Wang, D.; Qian, G.; Walmsley, J.C.; Holmen, A.; Chen, D.; Zhou, X. Fabrication of K-promoted iron/carbon nanotubes composite catalysts for the Fischer-Tropsch synthesis of lower olefins. J. Energy Chem. 2016, 25, 311-317. [CrossRef]

82. Zhang, Y.; Qing, M.; Wang, H.; Liu, X.-W.; Liu, S.; Wan, H.; Li, L.; Gao, X.; Yang, Y.; Wen, X.-D.; et al. Comprehensive understanding of $\mathrm{SiO}_{2}$-promoted Fe Fischer-Tropsch synthesis catalysts: $\mathrm{Fe}_{-} \mathrm{SiO}_{2}$ interaction and beyond. Catal. Today 2021, 368, 96-105. [CrossRef]

83. Ning, W.; Koizumi, N.; Chang, H.; Mochizuki, T.; Itoh, T.; Yamada, M. Phase transformation of unpromoted and promoted Fe catalysts and the formation of carbonaceous compounds during Fischer-Tropsch synthesis reaction. Appl. Catal. A Gen. 2006, 312, 35-44. [CrossRef]

84. Qing, M.; Yang, Y.; Wu, B.; Xu, J.; Zhang, C.; Gao, P.; Li, Y. Modification of $\mathrm{Fe}-\mathrm{SiO}_{2}$ interaction with zirconia for iron-based Fischer-Tropsch catalysts. J. Catal. 2011, 279, 111-122. [CrossRef]

85. Suo, H.; Wang, S.; Zhang, C.; Xu, J.; Wu, B.; Yang, Y.; Xiang, H.; Li, Y.W. Chemical and structural effects of silica in iron-based Fischer-Tropsch synthesis catalysts. J. Catal. 2012, 286, 111-123. [CrossRef]

86. Mogorosi, R.P.; Fischer, N.; Claeys, M.; van Steen, E. Strong-metal-support interaction by molecular design: Fe-silicate interactions in Fischer-Tropsch catalysts. J. Catal. 2012, 289, 140-150. [CrossRef]

87. Chang, Q.; Zhang, C.; Liu, C.; Wei, Y.; Cheruvathur, A.V.; Dugulan, A.I. Relationship between Iron Carbide $\mathrm{Phases}\left(\varepsilon-\mathrm{Fe}_{2} \mathrm{C}\right.$, $\mathrm{Fe}_{7} \mathrm{C}_{3}$, and $\chi-\mathrm{Fe}_{5} \mathrm{C}_{2}$ ) and Catalytic Performances of $\mathrm{Fe} / \mathrm{SiO}_{2}$ Fischer-Tropsch Catalysts. ACS Catal. 2018, 8, 3304-3316. [CrossRef]

88. Zhang, C.-H.; Wan, H.-J.; Yang, Y.; Xiang, H.-W.; Li, Y.-W. Study on the iron-silica interaction of a co-precipitated Fe/SiO2 Fischer-Tropsch synthesis catalyst. Catal. Commun. 2006, 7, 733-738. [CrossRef]

89. Xu, B.; Fan, Y.; Zhang, Y.; Tsubaki, N. Pore diffusion simulation model of bimodal catalyst for Fischer-Tropsch synthesis. AlChE J. 2005, 51, 2068-2076. [CrossRef]

90. Liu, Y.; Chen, J.-F.; Zhang, Y. The effect of pore size or iron particle size on the formation of light olefins in Fischer-Tropsch synthesis. RSC Adv. 2015, 5, 29002-29007. [CrossRef]

91. Toncón-Leal, C.F.; Múnera, J.F.; Arroyo-Gómez, J.J.; Sapag, K. Fe, Co and Fe/Co catalysts supported on SBA-15 for Fischer-Tropsch Synthesis. Catal. Today, 2021; in press. [CrossRef]

92. Cano, L.A.; Cagnoli, M.V.; Bengoa, J.F.; Marchetti, S.G. SBA-15 modified by incorporation of alkali metals: Effect of its structural changes on the catalytic properties of Fe/SBA-15 system in the Fischer-Tropsch Synthesis. Energy Technol. 2020, 7, $2194-4288$. [CrossRef]

93. Barrault, J.; Forquy, C.; Menezo, J.C.; Maurel, R. Selective hydrocondensation of CO to light olefins with alumina-supported iron catalysts. React. Kinet. Catal. Lett. 1980, 15, 153-158. [CrossRef] 
94. Baker, B.G.; Clark, N.J. Synthesis gas to motor fuel via light alkenes. In Studies in Surface Science and Catalysis; Bibby, D.M., Chang., C.D., Howe, R.F., Yurchak, S., Eds.; Elsevier: Amsterdam, The Netherlands, 1988; pp. 497-501. [CrossRef]

95. Perrichon, V.; Turlier, P.; Barrault, J.; Forquy, C.; Menezo, J.C. Hydrogenation of carbon monoxide on iron/alumina catalysts: Catalytic properties and the nature of the support. Appl. Catal. 1981, 1, 169-183. [CrossRef]

96. Adeleke, A.A.; Gnanamani, M.K. Alumina-supported iron catalyst-Long-term study of the light product distribution in Fischer-Tropsch synthesis. Mater Today Chem. 2021, 21, 100490. [CrossRef]

97. Xing, Y.; Jia, G.; Liu, Z.; Fang, S.; Zhao, C.; Guo, X.; Suib, S.L. Development of highly selective support for CO hydrogenation to light olefins with partially passivated iron catalysts. ChemCatChem 2019, 11, 3187-3199. [CrossRef]

98. Liu, Z.; Jia, G.; Zhao, C.; Xing, Y. Efficient Fischer-Tropsch to light olefins over iron-based catalyst with low methane selectivity and high olefin/paraffin ratio. Fuel 2021, 288, 119572. [CrossRef]

99. Dry, M.E.; Shingles, T.; Boshoff, L.J.; Oosthuizen, G.J. Heats of chemisorption on promoted iron surfaces and the role of alkali in Fischer-Tropsch synthesis. J. Catal. 1969, 15, 190-199. [CrossRef]

100. Liu, Z.; Jia, G.; Zhao, C.; Xing, Y. Selective iron catalysts for direct Fischer-Tropsch synthesis to light olefins. Ind. Eng. Chem. Res. 2021, 60, 6137-6146. [CrossRef]

101. Cheon, J.Y.; Kang, S.H.; Bae, J.W.; Park, S.J.; Jun, K.W.; Dhar, G.M.; Lee, K.Y. Effect of active component contents to catalytic performance on Fe-Cu-K/ZSM5 Fischer-Tropsch catalyst. Catal. Lett. 2010, 134, 233-241. [CrossRef]

102. Weber, J.L.; Krans, N.A.; Hofmann, J.P.; Hensen, E.J.M.; Zecevic, J.; De Jongh, P.E.; De Jong, K.P. Effect of proximity and support material on deactivation of bifunctional catalysts for the conversion of synthesis gas to olefins and aromatics. Catal. Today 2020, 342, 161-166. [CrossRef]

103. Lee, Y.-J.; Park, J.-Y.; Jun, K.-W.; Bae, J.W.; Viswanadham, N. Enhanced production of $\mathrm{C}_{2}-\mathrm{C}_{4}$ olefins directly from synthesis gas. Catal. Lett. 2008, 126, 149. [CrossRef]

104. Park, J.-Y.; Lee, Y.-J.; Jun, K.-W.; Bae, J.W.; Viswanadham, N.; Kim, Y.H. Direct conversion of synthesis gas to light olefins using dual bed reactor. J. Ind. Eng. Chem. 2009, 15, 847-853. [CrossRef]

105. Xu, L.Y.; Wang, Q.X.; Xu, Y.D.; Huang, J.S.; Cai, G.Y.; Chen, G.Q. Light olefins from syngas over modified Fischer-Tropsch catalysts. In Studies in Surface Science and Catalysis; Curry-Hyde, H.E., Howe, R.F., Eds.; Elsevier: Amsterdam, The Netherlands, 1994; pp. 473-478. [CrossRef]

106. Kang, S.-H.; Bae, J.W.; Sai Prasad, P.S.; Jun, K.-W. Fischer-Tropsch synthesis using zeolite-supported iron catalysts for the production of light hydrocarbons. Catal. Lett. 2008, 125, 264. [CrossRef]

107. Kang, S.-H.; Bae, J.W.; Woo, K.-J.; Sai Prasad, P.S.; Jun, K.-W. ZSM-5 supported iron catalysts for Fischer-Tropsch production of light olefin. Fuel. Process. Technol. 2010, 91, 399-403. [CrossRef]

108. Xu, Y.; Liu, J.; Ma, G.; Wang, J.; Wang, Q.; Lin, J.; Wang, H.; Zhang, C.; Ding, M. Synthesis of aromatics from syngas over FeMnK/SiO2 and HZSM-5 tandem catalysts. Mol. Catal. 2018, 454, 104-113. [CrossRef]

109. Xu, L.; Wang, Q.; Xu, Y.; Huang, J. Promotion effect of $\mathrm{K}_{2} \mathrm{O}$ and $\mathrm{MnO}$ additives on the selective production of light alkenes via syngas over Fe/silicalite-2 catalysts. Catal. Lett. 1995, 31, 253-266. [CrossRef]

110. Karre, A.V.; Kababji, A.; Kugler, E.L.; Dadyburjor, D.B. Effect of time on stream and temperature on upgraded products from Fischer-Tropsch synthesis when zeolite is added to iron-based activated-carbon-supported catalyst. Catal. Today 2013, $214,82-89$. [CrossRef]

111. Karre, A.V.; Kababji, A.; Kugler, E.L.; Dadyburjor, D.B. Effect of addition of zeolite to iron-based activated-carbon-supported catalyst for Fischer-Tropsch synthesis in separate beds and mixed beds. Catal. Today 2012, 198, 280-288. [CrossRef]

112. Hou, Y.; Li, J.; Qing, M.; Liu, C.-L.; Dong, W.-S. Direct synthesis of lower olefins from syngas via Fischer-Tropsch synthesis catalyzed by a dual-bed catalyst. Mol. Catal. 2020, 485, 110824. [CrossRef]

113. Bae, J.W.; Park, S.-J.; Kang, S.-H.; Lee, Y.-J.; Jun, K.-W.; Rhee, Y.-W. Effect of Cu content on the bifunctional Fischer-Tropsch Fe-Cu-K/ZSM5 catalyst. J. Ind. Eng. Chem. 2009, 15, 798-802. [CrossRef]

114. Zhu, C.; Huang, C.; Zhang, M.; Han, Y.; Fang, K. Rational design of hierarchical zeolite encapsulating FeMnK architecture to enhance light olefins selectivity in Fischer-Tropsch synthesis. Fuel 2022, 309, 122075. [CrossRef]

115. Yahyazadeh, A.; Dalai, A.K.; Ma, W.; Zhang, L. Fischer-Tropsch Synthesis for light olefins from syngas: A review of catalyst development. Reactions 2021, 2, 227-257. [CrossRef]

116. Ma, W.; Dalai, A.K. Effects of structure and particle size of iron, cobalt and ruthenium catalysts on Fischer-Tropsch Synthesis. Reactions 2021, 2, 62-77. [CrossRef] 